\title{
Possible Adverse Effects of High-Dose Nicotinamide: Mechanisms and Safety Assessment
}

\author{
Eun Seong Hwang * (i) and Seon Beom Song \\ Department of Life Science, University of Seoul, Dongdaemun-gu, Seoulsiripdae-ro 163, Seoul 02504, Korea; \\ scitiger@naver.com \\ * Correspondence: eshwang@uos.ac.kr; Tel.: +82-2-64-90-2-669
}

Received: 13 March 2020; Accepted: 21 April 2020; Published: 29 April 2020

\begin{abstract}
Nicotinamide (NAM) at doses far above those recommended for vitamins is suggested to be effective against a wide spectrum of diseases and conditions, including neurological dysfunctions, depression and other psychological disorders, and inflammatory diseases. Recent increases in public awareness on possible pro-longevity effects of nicotinamide adenine dinucleotide $\left(\mathrm{NAD}^{+}\right)$precursors have caused further growth of NAM consumption not only for clinical treatments, but also as a dietary supplement, raising concerns on the safety of its long-term use. However, possible adverse effects and their mechanisms are poorly understood. High-level NAM administration can exert negative effects through multiple routes. For example, NAM by itself inhibits poly(ADP-ribose) polymerases (PARPs), which protect genome integrity. Elevation of the $\mathrm{NAD}^{+}$pool alters cellular energy metabolism. Meanwhile, high-level NAM alters cellular methyl metabolism and affects methylation of DNA and proteins, leading to changes in cellular transcriptome and proteome. Also, methyl metabolites of NAM, namely methylnicotinamide, are predicted to play roles in certain diseases and conditions. In this review, a collective literature search was performed to provide a comprehensive list of possible adverse effects of NAM and to provide understanding of their underlying mechanisms and assessment of the raised safety concerns. Our review assures safety in current usage level of NAM, but also finds potential risks for epigenetic alterations associated with chronic use of NAM at high doses. It also suggests directions of the future studies to ensure safer application of NAM.
\end{abstract}

Keywords: nicotinamide; methylnicotinamide; $\mathrm{NAD}^{+}$; adverse effect; PARP; SIRT1; SIRT3; mitochondria; reactive oxygen species; DNA methylation

\section{Introduction}

Since Elvehjem et al. reported a cure for canine pellagra dogs using nicotinic acid amide (known as nicotinamide) in 1938 [1], nicotinamide (NAM) at doses far above those required as a vitamin (e.g., 500-3000 mg) has been applied to various diseases and conditions. Its usefulness has been observed in protection of neurons and vascular cells from ischemic reperfusion and similar oxidative stresses [2], prevention of neurological dysfunctions such as Alzheimer's and Parkinson's diseases [3-9], and treatment of depression and other psychological disorders $[10,11]$. The compound also showed promise against development of uremic pruritus, inflammatory diseases [12-14], photo-aging and skin cancers [15], and even HIV reproduction [16,17] (summarized in Table 1). The effectiveness of NAM on preventing onset of diabetes mellitus has been shown in some human studies $[18,19]$ although in later studies absence of such effect were also reported [20,21]. Some early studies also showed improvement of psychological conditions such as depression and anxiety in humans upon NAM treatment [22,23]. NAM is currently used against skin diseases such as bullous pemphigoid [24], skin 
cancers [25], and acne lesions [26]. Furthermore, it is widely added as an effective ingredient in various cosmetic products [27]. (Examples of human study results are shown in Table 2).

Table 1. Summary of beneficial effects of high doses of nicotinamide (NAM).

\begin{tabular}{|c|c|c|}
\hline Effects & Examples of Effects & References \\
\hline \multirow{9}{*}{ Neuroprotection } & Protection against ATP depletion & [2] \\
\hline & Decreased AD pathology and cognitive decline & [10] \\
\hline & Improved sensory and motor neurological behavior & [3] \\
\hline & Increased recovery from bilateral frontal brain injury & [4] \\
\hline & $\begin{array}{c}\text { Prevention/delay of ischemic stroke in stroke-prone } \\
\text { hypertensive rats }\end{array}$ & [5] \\
\hline & Reduced lateral geniculate nucleus neuronal death & [6] \\
\hline & $\begin{array}{l}\text { Attenuated hippocampal neuronal death after global } \\
\text { ischemia }\end{array}$ & [7] \\
\hline & $\begin{array}{l}\text { Improved motor deficits associated with } \\
\text { Huntington's disease phenotype }\end{array}$ & [8] \\
\hline & Increased $\mathrm{NAD}^{+}$level and mitochondrial function & [9] \\
\hline \multirow{2}{*}{$\begin{array}{l}\text { Amelioration of depression and } \\
\text { psychological disorders }\end{array}$} & Amelioration of depression & [28] \\
\hline & Increased social interaction & [11] \\
\hline \multirow[t]{2}{*}{ Anti-inflammation } & $\begin{array}{c}\text { Attenuated neutrophil recruitment in } \\
\text { carrageenan-induced pleurisy or in lesions of } \\
\text { autoimmune disease }\end{array}$ & {$[12,13]$} \\
\hline & Reduced arthritis activity & [14] \\
\hline \multirow{2}{*}{$\begin{array}{l}\text { Protection against } \\
\text { vision and hearing loss }\end{array}$} & $\begin{array}{l}\text { Attenuated retinal pigment cell death and } \\
\text { age-related macular degeneration in animals }\end{array}$ & [29] \\
\hline & $\begin{array}{l}\text { Reduced incidence of optic nerve degeneration and } \\
\text { glaucoma }\end{array}$ & {$[30,31]$} \\
\hline Immune modulation & $\begin{array}{l}\text { Improved mouse survival after lethal Staphylococcus } \\
\text { enterotoxin B challenge }\end{array}$ & [32] \\
\hline $\begin{array}{l}\text { Skin protection/anti- } \\
\text { skin disorders/cosmetic } \\
\text { effects }\end{array}$ & $\begin{array}{l}\text { Downregulation of the expression of inflammatory } \\
\text { cytokines and protection against UV light }\end{array}$ & [33] \\
\hline Anti-fibrosis & Attenuated development of pulmonary fibrosis & {$[34,35]$} \\
\hline \multirow{2}{*}{$\begin{array}{l}\text { Anti-metastasis and } \\
\text { adjuvant cancer therapy }\end{array}$} & Decreased growth and progression of bladder tumors & {$[36,37]$} \\
\hline & $\begin{array}{l}\text { Photo-protection and reduced incidence of skin } \\
\text { cancers }\end{array}$ & [15] \\
\hline \multirow{2}{*}{ Anti-HIV and -AIDS } & Decreased provirus integration & [16] \\
\hline & Decreased viral RNA expression & [17] \\
\hline
\end{tabular}


Table 2. Positive and negative effects of NAM shown in human studies ${ }^{1}$.

\begin{tabular}{|c|c|c|c|}
\hline $\begin{array}{l}\text { Affected Organs and } \\
\text { Conditions }^{2}\end{array}$ & Observed Effects & Dose and Duration & References \\
\hline \multicolumn{4}{|l|}{ Beneficial effects } \\
\hline Joints & $\begin{array}{l}\text { Reduced itching in uremic } \\
\text { patients }\end{array}$ & $\begin{array}{l}550 \text { mg twice a day } \\
\text { (4 weeks) }\end{array}$ & [38] \\
\hline \multirow{4}{*}{ pancreatic $\beta$-cell } & $\begin{array}{l}\beta \text {-cell function preserved and } \\
\text { improved }\end{array}$ & $\begin{array}{c}25 \mathrm{mg} / \mathrm{kg} \text { daily intake } \\
\text { (4 weeks) }\end{array}$ & {$[18,39]$} \\
\hline & $\begin{array}{l}\text { Reduced the rate of diabetes } \\
\text { incidence }\end{array}$ & $\begin{array}{l}500 \mathrm{mg} \text { twice per day } \\
\text { (2.5 years) }\end{array}$ & [19] \\
\hline & $\begin{array}{l}\text { No effect on the incidence of being } \\
\text { diabetes-free }\end{array}$ & $\begin{array}{l}1200 \text { mg daily intake } \\
\text { (5 years) }\end{array}$ & {$[20]$} \\
\hline & $\begin{array}{l}\text { Ineffective in prevention or } \\
\text { delaying clinical onset of diabetes }\end{array}$ & $\begin{array}{l}1.2 \text { g daily intake } \\
\text { (3 years) }\end{array}$ & [21] \\
\hline \multirow{2}{*}{ Skin } & Reduced acne lesions and severity & $\begin{array}{l}4 \% \text { gel } \\
\text { applied twice daily } \\
(8 \text { weeks })\end{array}$ & {$[26]$} \\
\hline & $\begin{array}{l}\text { Attenuated immunosuppression } \\
\text { with alterations in metabolism } \\
\text { and apoptosis }\end{array}$ & $\begin{array}{l}\text { 5\% lotion applied before } \\
\text { UV exposure }\end{array}$ & {$[40]$} \\
\hline \multirow{2}{*}{ Psychology } & Improvements against depression & $\begin{array}{c}0.5-1.5 \mathrm{~g} \text { daily intake } \\
\text { (3 weeks) }\end{array}$ & [22] \\
\hline & Relief from anxiety & $\begin{array}{l}\text { A dose of } 2 \mathrm{ug} \\
3 \mathrm{~h} \text { prior to test }\end{array}$ & [23] \\
\hline Kidney & $\begin{array}{l}\text { Lowered serum concentrations of } \\
\text { phosphorus, parathyroid } \\
\text { hormone, and LDL, and increased } \\
\text { serum HDL }\end{array}$ & $\begin{array}{c}500 \mathrm{mg} / \text { day (with and } \\
\text { increment every } 2 \text { weeks) } \\
\text { (12 weeks) }\end{array}$ & [41] \\
\hline $\begin{array}{l}\text { Skin cancers } \\
\text { non-melanoma }\end{array}$ & $\begin{array}{l}\text { Reduced incidence of various } \\
\text { types of skin cancers and actinic } \\
\text { keratoses }\end{array}$ & $\begin{array}{l}500 \text { mg twice daily } \\
\text { (4 months) }\end{array}$ & {$[42]$} \\
\hline \multicolumn{4}{|l|}{ Adverse Effects } \\
\hline Minor effects & $\begin{array}{l}\text { Frontal dull headaches, nausea, } \\
\text { headache, dizziness }\end{array}$ & $\begin{array}{c}1-18 \mathrm{~g} \\
\text { immediate }\end{array}$ & {$[43,44]$} \\
\hline Pancreatic $\beta$-cell/plasma & $\begin{array}{l}\text { Decreased insulin sensitivity, } \\
\text { increased oxidative stress }\left(\mathrm{H}_{2} \mathrm{O}_{2}\right)\end{array}$ & $\begin{array}{l}2 \text { g daily } \\
\text { (2 weeks) }\end{array}$ & {$[45,46]$} \\
\hline Liver & $\begin{array}{c}\text { Parenchymal-cell injury, portal } \\
\text { fibrosis and cholestasis, liver } \\
\text { injury }\end{array}$ & $\begin{array}{l}3,9 \text { g daily } \\
(10 \text { days })\end{array}$ & [47] \\
\hline Lymphocytes, platelets & $\begin{array}{l}\text { Uremic toxicity-related cancer and } \\
\text { thrombocytopenia }\end{array}$ & $\begin{array}{l}\text { 1300, } 1500 \text { mg daily } \\
\text { (24 weeks) }\end{array}$ & {$[48]$} \\
\hline Kidney/platelets & $\begin{array}{l}\text { Decreased serum phosphorus and } \\
\text { thrombocytopenia }\end{array}$ & $\begin{array}{l}0.52-2 \text { g daily } \\
\text { (3-6 months) }\end{array}$ & {$[49,50]$} \\
\hline
\end{tabular}

\footnotetext{
${ }^{1}$ Some examples of human studies are presented. For more information on the beneficiary effects, check Reference [27].

${ }^{2}$ In all human applications except for skin, NAM was administered through dietary intake.
}

Since the early 1940s, NAM and niacin (also known as nicotinic acid (NA)) have been heavily consumed as food supplements in the USA. Per capita consumption of niacin in the USA has doubled since implementation of mandatory niacin fortification in the early 1940s [51]. Due to the growing 
demand for NAM in food additives, cosmetic supplements, and dietary pills, its production has continuously grown. Furthermore, a recent increase in public awareness on the beneficial effects of NAM has caused substantial growth of its production, from 56.520 metric tons in 2012 to 71.192 metric tons in 2016, an increase of 30 \% (Global Nicotinamide Market Research Report 2017).

NAM's efficacy as a therapeutic agent may not be as acute or as strong as that of drugs targeting a particular enzyme. The effects of NAM are, in most part, mediated by increase in the level of nicotinamide adenine dinucleotide $\left(\mathrm{NAD}^{+}\right)$, which plays important roles in metabolic homeostasis, and activities of certain enzymes that play critical roles in health and longevity. SIRT1, for example, is a molecule that plays important roles against age-associated dysfunction as well as in resistance to oxidative stress. Levels of both $\mathrm{NAD}^{+}$and SIRT1 activity decline with aging. Counter-balancing this change through $\mathrm{NAD}^{+}$supplementation has been proposed as beneficial for healthy aging in animal and human studies [52]. Therefore, long-term intake of NAM as a dietary supplement is tempting. This trend demands an assurance of safety and a clear understanding of the mechanisms of action of NAM. Literature reviews have presented various beneficial effects of NAM and the underlying mechanisms (e.g., Song, 2019) [27]. However, there is a current lack of assessment on NAM's potential adverse effects. Studies reporting such effects are scattered, and a comprehensive analysis has not yet been performed. This review presents a collective literature search on the possible adverse effects of NAM and offers a comprehensive analysis on the possible underlying molecular mechanisms.

\section{Briefs on Biochemistry Associated with Mechanisms Underlying NAM's Positive Effects}

In human cells, NAM is readily converted to nicotinamide mononucleotide (NMN) and then to nicotinamide adenine dinucleotide $\left(\mathrm{NAD}^{+}\right)$. This salvage pathway for cellular $\mathrm{NAD}^{+}$production appears to be a key route in many of the NAM effects. In support of this, most of NAM's effects are abolished by inhibition of nicotinamide adenine mononucleotide phosphotransferase (Nampt) [53], which catalyzes NAM conversion to NMN (Figure 1). In addition, the effects of other NAD ${ }^{+}$precursors, namely NA and nicotinamide riboside (NR), overlap largely with those of NAM.

Cellular $\mathrm{NAD}^{+}$level and, thereby, the $\mathrm{NAD}^{+} / \mathrm{NADH}$ ratio affect not only ATP synthesis, but also generation of reactive oxygen species (ROS) [54,55]. Therefore, $\mathrm{NAD}^{+}$is believed to be involved in aging as well as many pathological conditions [56]. NAM-mediated increase in NAD ${ }^{+}$level lead to reduced ROS generation from mitochondria through multiple mechanisms (summarized in Figure 1). First, elevation in $\mathrm{NAD}^{+} / \mathrm{NADH}$ leads to reduced mitochondrial membrane potential, decreasing the chance for superoxide generation through retro-transport of electrons [55,57]. Second, high $\mathrm{NAD}^{+}$level facilitates activation of proteins involved in mitochondria quality control, such as SIRT1 and SIRT3, NAD ${ }^{+}$-dependent deacetylases functioning in metabolic homeostasis, cell survival and proliferation, stress resistance, and mitochondria maintenance $[27,58]$. SIRT1 activity facilitates mitochondrial maintenance by promoting their turnover through mobilization of factors involved in mitochondria biogenesis (peroxisome proliferator-activated receptor gamma coactivator-1 $\alpha$ (PGC-1) $\alpha$ ) and mitophagy (autophagy gene proteins, ATGs) [27]. It also facilitates cellular anti-oxidative defense through activation of forkhead box protein $\mathrm{O}(\mathrm{FoxO})$ proteins, which induce manganese-dependent superoxide dismutase (MnSOD) and catalase [59]. Meanwhile, SIRT3 activity suppresses mitochondrial ROS generation through activation of MnSOD [60,61]. It also promotes mitochondrial integrity by inducing closure of the mitochondrial permeability transition pore (mPTP) through deacetylation of mitochondrial matrix protein cyclophilin D [62]. These anti-oxidative and pro-mitochondrial effects of SIRT1 and SIRT3 proteins function critically in protection of neurons and other cells that are otherwise vulnerable to oxidative stress $[2,63,64]$ and in extension of in vitro replicative life spans of human cells, including bone marrow stem cells [55,65-68]. Third, NAM's anti-oxidative effects may also be driven by direct inhibition of poly (ADP-ribose) polymerases (PARPs). PARPs protect genome integrity by binding to DNA at the sites of strand breaks and recruiting DNA repair enzymes. In doing so, they degrade $\mathrm{NAD}^{+}$and generate NAM and ADP-ribose [69-72]. Activated PARPs induce inflammation through activation of nuclear factor- $\mathrm{KB}$ (NF- $\mathrm{KB}$ ) [73]. By acting as a feedback inhibitor to 
PARPs, NAM attenuates inflammation and thereby exerts anti-oxidative and therapeutic effects against inflammation-associated diseases [38,74-76]. NAM also protects cells with severe DNA damage from apoptotic or necrotic death caused by PARP-induced depletion of $\mathrm{NAD}^{+}$and ATP pools. Indeed, attenuated death of pancreatic $\beta$-cells in animals upon NAM administration is proposed to be driven by PARP inhibition-mediated cell protection, enhanced mitochondrial integrity, and reduced ROS generation $[77,78]$.

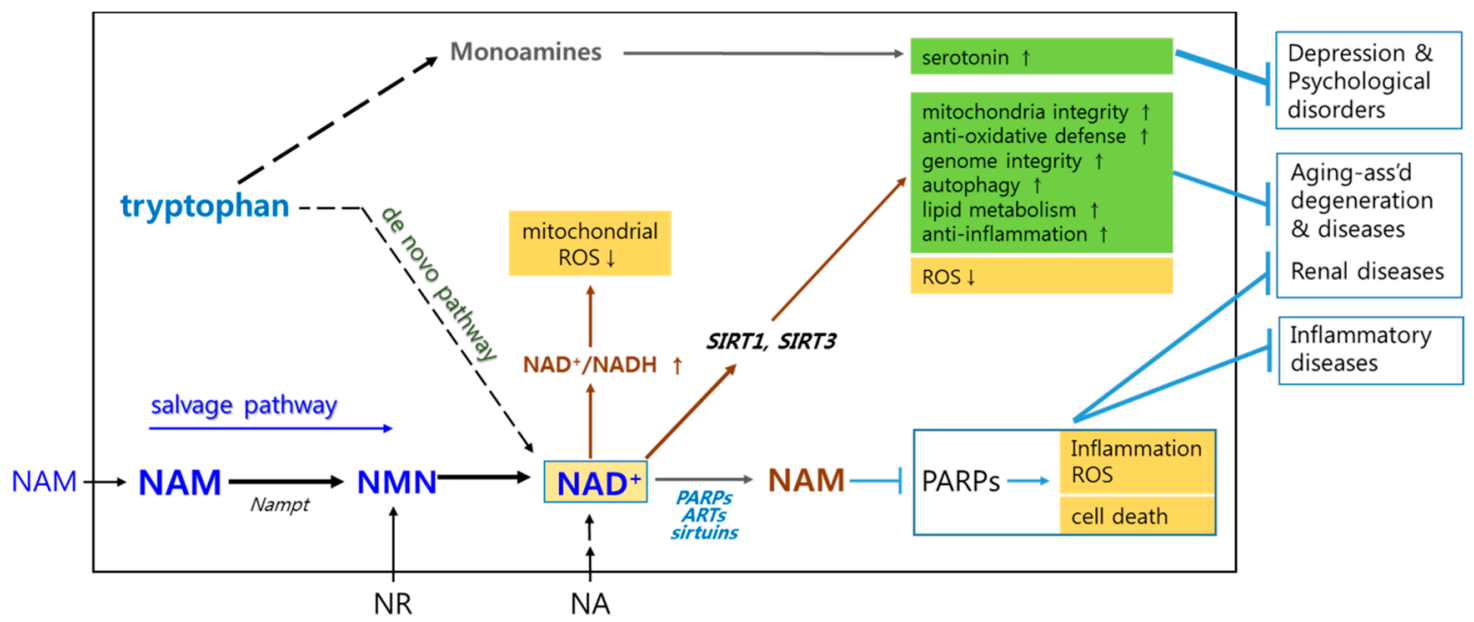

Figure 1. A schematic representation of routes of metabolism and beneficiary effects of NAM. In cells (grey-lined box), NAM is converted to nicotinamide adenine dinucleotide $\left(\mathrm{NAD}^{+}\right)$mainly through salvage pathways via nicotinamide mononucleotide $(\mathrm{NMN})$. $\mathrm{NAD}^{+}$is reduced to become $\mathrm{NADH}$ and thereby, establishes $\mathrm{NAD}^{+}$redox, through which NAM treatment affects mitochondrial energetics and ROS generation. $\mathrm{NAD}^{+}$is also broken down to NAM and ADP-ribose by poly(ADP-ribose) polymerases (PARPs), sirtuins, and a family of ADP-ribose transferases (ARTs), to which NAM exerts feedback inhibition. Among these, inhibition of PARPs constitutes an important route of anti-inflammatory, anti-oxidative, and pro-cell survival effects. Increased level of $\mathrm{NAD}^{+}$activates sirtuin proteins such as SIRT1 and SIRT3, which exert a variety of cell-beneficiary effects such as anti-oxidation, genome stability, autophagy, and lipid metabolism. In addition, they together maintain mitochondria quality and integrity, and thereby, keep reactive oxygen species (ROS) generation at low level. Through these, NAM may exert effects against aging-associated degeneration and diseases, and renal and inflammatory diseases. Through these effects, NAM may help protecting neurons and pancreatic $\beta$-cells. Meanwhile, a minor portion of cellular $\mathrm{NAD}^{+}$pool is provided through de novo synthesis from tryptophan, which is also a source for serotonin. Therefore, NAM supplement helps maintaining serotonin level, and thereby alleviates depression and psychological disorders. NAD ${ }^{+}$level is also elevated through supplementation of nicotinamide riboside (NR) and nicotinic acid (NA).

Activation of SIRT1 brings in many other therapeutically useful effects by deacetylation-mediated activation of target molecules. Examples include: enhanced lipid degradation and fatty acid oxidation through activation of peroxisome proliferator-activated receptor (PPAR)- $\alpha$ and $-\gamma$ [79-81]; protection of genome integrity through activation of $\mathrm{Ku} 70$, a member of the DNA repair machinery [82]; and suppression of inflammation and apoptosis through inhibition of NF-kB [83] and p53 [84]. Together, these effects can protect against age-associated degeneration and diseases [85]. Inhibition of PARPs and NF- $\kappa$ B by NAM as well as NAD ${ }^{+}$-mediated SIRT1 activation alleviate inflammation, oxidative stress, fibrosis, and apoptosis of renal cells, which are key etiological problems of kidney disease [86].

NAM administration-induced elevation of $\mathrm{NAD}^{+}$level supports renal and fecal Pi excretion and alleviates hyperphosphatemia, which is frequently associated with end-phase renal insufficiency [87]. $\mathrm{NAD}^{+}$inhibits $\mathrm{Na}+$-phosphate cotransporters (NaPi2a and $\mathrm{NaPi} 2 \mathrm{~b}$ ), major routes for phosphate uptake in renal proximal tubule and intestine [88,89]. 
Finally, NAM has been shown to ameliorate depression and psychological disorders. It was also shown effective against a wider spectrum of mental disorders and other complaints including migraines, dizziness, motion sickness, bipolar and behavioral disorders, alcohol dependence, and trophic deprivation-mediated neuronal death [90]. NAM may act in such circumstance by elevating levels of monoamine neurotransmitters including serotonin, a mood-stabilizing hormone that is synthesized from tryptophan. A minor portion of cellular $\mathrm{NAD}^{+}$is supplied by de novo synthesis from tryptophan [91]. NAM supplementation would lower the need for de novo $\mathrm{NAD}^{+}$synthesis and thereby reserve tryptophan for continued serotonin synthesis [92].

\section{Potential Toxicity and Adverse Effects of High Doses of NAM}

NAM at doses near $5 \mathrm{mM}$ exerts positive effects on viability and replication potential of cells in culture [65,93]. However, at doses above $20 \mathrm{mM}$, NAM causes apoptotic death, with a reported half inhibitory concentration (IC50), or half-cell-killing dose, of $21.5 \mathrm{mM}[94,95]$. Therefore, in vitro, there is a narrow gap between the effective and toxic doses of NAM. Animal studies have shown the lethal dose in $50 \%$ of the sample $\left(\mathrm{LD}_{50}\right)$ of NAM to be $2.5 \mathrm{~g} / \mathrm{kg}$ for oral administration and $2.05 \mathrm{~g} / \mathrm{kg}$ intraperitoneal administration in mice and slightly higher in rats [96]. These doses approach 150 and $120 \mathrm{~g}$, respectively, when extrapolated to humans. The lethality of these high doses of NAM can be attributed to osmotic shock from the hypertonic solution rather than to biochemical effects. Meanwhile, tolerance of doses near $1 \mathrm{~g}$ (or up to $3 \mathrm{~g}$ ) of daily intake of NAM, even during long-term administration, has been demonstrated in many studies. Examples are the European Nicotinamide Diabetes Intervention Trial (ENDIT), where children were treated with $25-50 \mathrm{mg} / \mathrm{kg}$ a day for 5 years without reported adverse effects $[20,97]$ and a recent clinical study which showed that intake of $1.5 \mathrm{~g}$ NAM twice daily for 6 months was safe in elderlies [NCT00580931]. These studies assure safety in the current wide-spread practice of long-term dietary intake of 500-1000 mg per day. Although headache, dizziness, and vomiting occurred in healthy humans when NAM at doses up to $6 \mathrm{~g}$ was ingested on an empty stomach [43], these adverse effects were minor and resolved upon termination. However, NAM administration above certain levels has shown adverse effects in animals. Moreover, the biochemical nature of NAM raises concerns on potential adverse effects of administration. For this reason, both NAM and its metabolites need to be analyzed in depth for their properties and mechanisms of action (summarized in Table 3 and Figure 2).

\subsection{Possible Genotoxicity and Carcinogenicity: Inconclusive Effects of NAM}

NAM inhibits the activity of PARPs, which function in recognizing and inducing repair of DNA strand breaks. Therefore, suppression of PARP activity raises reasonable concerns on loss of DNA integrity or enhanced sister chromatid exchange (SCE) [98], which may causatively be associated with certain types of cancers [99]. For this reason, the carcinogenic and co-carcinogenic effects of NAM have been the focus of early studies. However, results in large are not conclusive in both the cases. For instance, treatment with 1-10 mM NAM or other PARP inhibitors, but not with NA, resulted in an increase in SCE $[100,101]$, and 25 mM NAM treatment induced a large structural aberration of chromosomes in Chinese Hamster Ovary cells [102]. On the other hand, NAM deficiency augmented the SCE-inducing potential of PARP inhibitors [103]. This may suggest a PARP-independent effect of NAM in chromatid protection. SIRT1 activation-mediated protection of DNA integrity [82] could be involved which was not considered at the time of the study. Meanwhile, when the mutagenic potential of NAM was assessed using Ames tests with Salmonella or Chinese Hamster fibroblasts, the results showed a null effect [104]. In addition, an increase in DNA repair was reported after gamma- or UV-radiation upon treatment with NAM at doses near $3 \mathrm{mM}$ [105]. Studies on co-carcinogenic effects of NAM are also inconclusive. 
Table 3. Examples of adverse effects of high dose NAM reported in studies of cells and animals.

\begin{tabular}{|c|c|c|c|c|}
\hline Subjects & Examples of Effects & Dose & Duration & Ref. \\
\hline \multirow{5}{*}{ Cells } & Death of mouse embryonic stem cells & $20 \mathrm{mM}$ & 3-4 days & [95] \\
\hline & \multirow{2}{*}{$\begin{array}{l}\text { Tumorigenicity. DNA damage, and sister } \\
\text { chromatid exchanges }\end{array}$} & $\begin{array}{c}1-10 \mathrm{mM} \\
10 \mathrm{mM}\end{array}$ & $\begin{array}{l}3 \mathrm{~h} \\
40 \mathrm{~h}\end{array}$ & {$[100,101]$} \\
\hline & & $25 \mathrm{mM}$ & $48 \mathrm{~h}$ & [102] \\
\hline & $\begin{array}{l}\text { Decreased SIRT1 activity. Increased } \\
\text { intracellular ROS, spindle defects, and } \\
\text { mitochondria dysfunction }\end{array}$ & $5 \mathrm{mM}$ & $6,12,24 \mathrm{~h}$ & [106] \\
\hline & $\begin{array}{l}\text { Blocked mitochondria-related transcription. } \\
\text { Worsened motor disturbance in } \\
\text { Huntington's disease model }\end{array}$ & $0.5,1 \mathrm{mM}$ & $96 \mathrm{~h}$ & [9] \\
\hline \multirow{10}{*}{ Mice and Rats } & $\begin{array}{l}\text { Oxidative DNA damage in hepatic and } \\
\text { renal tissues. Impaired glucose tolerance } \\
\text { and insulin sensitivity }\end{array}$ & 1 or $4 \mathrm{~g} / \mathrm{kg}$, d.w. & 8 weeks & [94] \\
\hline & Increased lethality & $\begin{array}{l}4.5 \mathrm{~g} / \mathrm{kg} \text {, d.w., } \\
2.5 \mathrm{~g} / \mathrm{kg} \text {, i.p. }\end{array}$ & 40 days & [44] \\
\hline & Occurrence of pancreatic islet cell tumor & $350 \mathrm{mg} / \mathrm{kg}$, i.p. & 226 days & [107] \\
\hline & Increased incidence of kidney tumors & $350 \mathrm{mg} / \mathrm{kg}$, i.p. & until die & [108] \\
\hline & Decreased growth rate & $\begin{array}{l}1,2 \% \text {, d.w. } \\
1,2 \% \text {, d.w. }\end{array}$ & $\begin{array}{l}24 \text { days } \\
20 \text { days }\end{array}$ & {$[109,110]$} \\
\hline & $\begin{array}{l}\text { Growth inhibition, methyl deficiency, } \\
\text { reduced tissue choline level, and increased } \\
\text { hepatic lipids }\end{array}$ & 6, 20, $60 \mathrm{mg} / 100 \mathrm{~g}$ bw, i.p. & 2,5 weeks & [111] \\
\hline & $\begin{array}{l}\text { Amelioration of acetaminophen-induced } \\
\text { biochemical changes but occurrence of } \\
\text { hepatotoxicity in healthy animals }\end{array}$ & 500 mg/kg, i.p. & $1.5 \mathrm{~h}$ & [112] \\
\hline & $\begin{array}{c}\text { Development of hepatic steatosis and } \\
\text { fibrosis }\end{array}$ & $1 \%$, d.w. & $\begin{array}{l}6 \text { weeks, } \\
7 \text { months }\end{array}$ & [113] \\
\hline & $\begin{array}{c}\text { Neurodegeneration of dopaminergic } \\
\text { neurons } \\
\text { Behavioral deficits and structural brain } \\
\text { changes }\end{array}$ & $500 \mathrm{mg} / \mathrm{kg}$, i.p. & 28 days & [114] \\
\hline & $\begin{array}{l}\text { Blocked mitochondrial-related } \\
\text { transcription, worsened motor phenotype }\end{array}$ & 250 mg/kg/day, s.c. & 28 days & [9] \\
\hline
\end{tabular}

i.p., intraperitoneal injection; d.w., drinking water; and s.c., subcutaneous injection.

For example, pancreatic islet tumors were formed in $64 \%$ of rats intraperitoneally administered NAM $(350 \mathrm{mg} / \mathrm{kg})$ and streptozotocin together, while one or no tumors was formed in rats given either NAM or streptozotocin alone [107]. However, a significant reduction of renal adenoma by co-treatment with NAM was reported by the same group [115]. Meanwhile, NAM (350 mg/kg, i.p), when treated with the carcinogen diethylnitrosamine increased the incidence of kidney tumors but decreased that of liver tumors [108]. This suggests an organ-specific co-carcinogenic effect of NAM, but the underlying reasons are unknown. NAM may act differently at different stages of tumor initiation and tumor promotion. Overall, the effects of NAM on carcinogenesis or tumor promotion are not clear, raising considerable concerns regarding long-term intake of NAM. Perhaps, a follow-up study on the subjects of the ENDIT study, which was carried out more than 20 years ago for 5 years and which touted the safety of high doses of NAM, may provide critical information in this regard. Meanwhile, NAM is being clinically tested for possible anti-carcinogenic effects against lung cancer [NCT02416739]. 


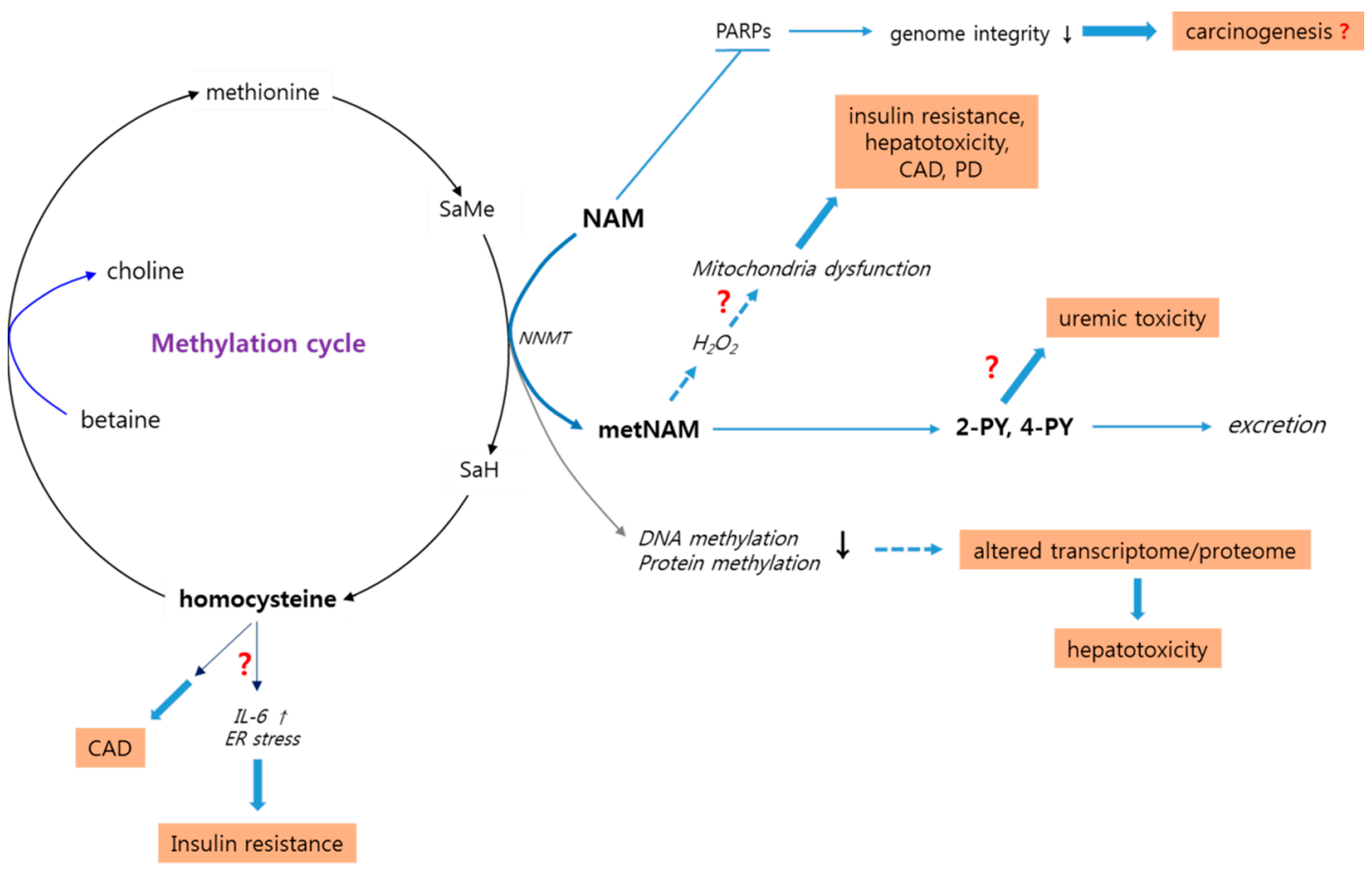

Figure 2. Routes of possible adverse effects of high doses of NAM. High-level NAM has been proposed to induce disorders through multiple different routes. First, NAM inhibits PARP proteins, thereby inducing anti-inflammatory effects but also causing genome instability, which may lead to carcinogenesis. Second, methylation of large amounts of NAM can lower the cellular methyl pool. This leads to reduced methylation of DNA and proteins, thereby changing patterns of gene expression and protein activity. This is proposed to be etiologically linked to liver steatosis and fibrosis. Meanwhile, NAM methylation yields metNAM, which, by inducing high level ROS generation and subsequent dysfunction of mitochondria, may cause development of insulin resistance, coronary artery disease (CAD), and Parkinson's disease (PD). However, it is not clear whether metNAM-induced ROS generation is harmful. MetNAM is further metabolized to N-methyl-2-pyridone-5-carboxamide (2-PY), whose elevated blood levels can be toxic to patients with chronic renal problems. Meanwhile, increase in the methylation cycle by high-level NAM would lead to an increase in the level of homocysteine, which, by upregulating interleukin-6 (IL-6) expression and inducing endoplasmic reticulum (ER) stress, may trigger insulin resistance and CAD. However, most of these proposed links between high-level NAM and the conditions are poorly supported by experimental evidence.

\subsection{Inhibition of Sirtuin Activity: An Effect that May Not Be Important In Vivo}

Like PARPs, sirtuin family proteins are susceptible to feedback inhibition by NAM. Hence, NAM has been a favored inhibitor in experiments involving SIRT1 activity in certain biological functions [46]. For instance, in a study on the role of SIRT1 in reducing triglyceride levels in differentiating adipocytes, $10 \mu \mathrm{M}$ NAM attenuated SIRT1-mediated reduction of triglyceride levels [116]. This inhibition, if it occurs in vivo, would result in a serious decline in body functions. However, in many of the studies, the observed inhibitory effects of NAM were not conclusive. For instance, treatment with NAM decreased activities of sirtuin proteins in mouse oocytes when examined at 6 or $12 \mathrm{~h}$ after treatment, but this effect was not reproduced when examined at $24 \mathrm{~h}$ [106]. Observations indicate that a cellular state of high [NAM] is brief in treated subjects. Upon treatment through peritonea or gavage route, tissue NAM level increased immediately and reached nearly four-fold induction within 10 min (in livers of mice administered by gavage). However, this level then decreased and was sustained at a level nearly two-fold higher than basal $[46,117]$. Upon dietary intake of high doses of NAM, elevated level in blood is also maintained for 2 hours [46]. Similar to NAM, the level of NAD ${ }^{+}$was shown to increases from similar early time points and remains at the elevated level for more than $12 \mathrm{~h}$ in animal tissues [117] 
and cultured human cells [65]. Therefore, in cells and animals treated with NAM, activities of sirtuin proteins would briefly be suppressed, soon followed by prolonged activation. This pattern of SIRT1 inhibition by NAM in vivo is expected to be different from that of PARPs. While PARPs are acutely activated upon DNA damage and consume $\mathrm{NAD}^{+}[118]$, sirtuins remain minimally inactive and are activated only by high level of $\mathrm{NAD}^{+}[46]$. Hence, when PARP is activated, the presence of a high level of NAM results in acute and substantial suppression of its activation. In contrast, sirtuin activities would be drop only marginally and transiently and elevated upon subsequent increase in NAD ${ }^{+}$ level. Furthermore, the IC50 of NAM is lower with PARP-1 $(31 \mu \mathrm{M})$ than with SIRT1 (50-180 $\mu \mathrm{M})$ [46], indicating that PARP-1 is more sensitively affected by NAM administration than is SIRT1.

\subsection{High $N A D^{+} / \mathrm{NADH}$ Ratio: Concerns Regarding Energy Metabolism}

In a study on human fibroblasts, NAM treatment lowered cellular ATP level by approximately $10 \%$ after 3-day treatment at $5 \mathrm{mM}$ [65]. This is due to an increase of $\mathrm{NAD}^{+}$level and the associated decrease in $\mathrm{NADH} / \mathrm{NAD}^{+}$in mitochondria, which leads to reduced electron supply for the electron transport chain and a decrease in oxidative phosphorylation [55]. If this effect occurs in vivo, physiological activities and organ functions that demand a high level of ATP could be affected, which raises concerns against unguided intake of NAM. In an early study, a decreased growth rate was reported in rats receiving 1 or $2 \mathrm{~g} / \mathrm{kg}$ NAM for 40 days [109,110]. NAM treatment did not alter proliferation rates of cells in culture but did affect cell size $[55,65,68]$. Flow cytometric analyses of human fibroblasts and bone marrow stem cells showed an approximately 10\% reduction in forward scattering (an indication of cell surface) upon NAM treatment (S. Song and E. Hwang, data not shown). Meanwhile, in a later study by Handler and Dann [110], the authors suspected that the decreased growth rate was attributed to synthesis of metNAM.

\subsection{High-Level NAD ${ }^{+}$: Effect on Protein Translation}

$\mathrm{NAD}^{+}$is found to be added to the $5^{\prime}$ ends of mRNAs and noncoding RNAs of both prokaryotes and eukaryotes, including humans [50]. Normally, 5',5'-triphosphate-linked N7-methylguanosine is added at the first nucleotide of mRNA, forming the m7G cap [119], which protects mRNA from degradation and functions as an acceptor for the translation initiation complex [120]. In contrast, $\mathrm{NAD}^{+}$-capped mRNAs are poorly translated and degraded rapidly [50]. Although little is known about the function and regulation of $\mathrm{NAD}^{+}$-capping in human cells, this may occur more frequently when $\mathrm{NAD}^{+}$is in high abundance. Perhaps NAD ${ }^{+}$level may link cellular energetics to protein translation efficiency. If this is the case, a high level of $\mathrm{NAD}^{+}$would have a global impact on cellular protein levels, and its intervention may have a serious impact on bodily homeostasis as well as development of disease such as cancer. More information should be gathered to address this safety concern.

\subsection{High-Level NAM Methylation: Potential Effects of Altered Methyl Pool}

NAM ingested roughly at $200 \mu \mathrm{mol}$ (or $0.3 \mathrm{mg} / \mathrm{kg}$ ) daily (for healthy adults at normal diet conditions) [121] is metabolized mainly in the liver by cytochrome p450. It is first methylated by nicotinamide-N-methyltransferase (NNMT) to N-methyl-nicotinamide (metNAM), which is further metabolized to N-methyl-2-pyridone-5-carboxamide (2-PY) or N-methyl-4-pyridone-5-carboxamide (4-PY). Approximately $17.5 \mu \mathrm{mol}$ is excreted in urine in the form of these metabolites [122,123]. NAM is also oxidized to nicotinamide-N-oxide or hydroxylated to 6-hydroxy-nicotinamide, but the roles of these metabolites are insignificant in humans or unknown yet.

NAM methylation affects cellular availability of methyl groups, which are used predominantly to methylate DNA and proteins. DNA methylation at cytosines of $\mathrm{CpG}$ sites modulates gene expression [124]. Aberrant DNA methylation is involved in obesity and type 2 diabetes [125,126]. Protein methylation at arginine and lysine residues modulates protein function [127]. For example, histone methylation affects histone's regulatory roles in gene expression. Adequate levels of the cellular methyl pool and methyl metabolism are therefore important for cellular homeostasis, especially in 
regulating gene expression. A methyl group is transferred from methionine to S-adenosylmethionine (SAMe) in the S-adenosylmethionine cycle (or methylation cycle). SAMe, in turn, yields the methyl group to DNA and proteins and becomes homocysteine, which is converted to methionine by accepting a methyl group from 5-methyltetrahydrofolate (5-MTHF) in a pathway dependent on betaine or folate [128] (Figure 2). NAM act in this cycle as another acceptor of methyl groups. Nicotinamide N-methyltransferase (NNMT) mediates the transfer of methyl groups from SAMe to NAM (Figure 2). Under normal conditions, the NAM concentration in human blood is $69 \mu \mathrm{M}$ [129], producing inefficient NAM methylation since the $\mathrm{K}_{\mathrm{M}}$ of the human NNMT for NAM, at approximately $430 \mu \mathrm{M}$, is rather high [130]. However, an increase in NAM level leads to a proportional increase of NAM methylation, which is accompanied by a decrease in plasma betaine concentration $[111,131]$. In rodents, administration of high doses of NAM caused liver steatosis and kidney hypertrophy, effects that were attributed to depletion of methyl donors [111]. Furthermore, dietary intake of $1 \mathrm{or} 4 \mathrm{~g} / \mathrm{kg}$ of NAM altered the expression of genes involved in methyl metabolism in rats [94]. In these studies, however, the amount of NAM was relatively high, equivalent to 50-200 $\mathrm{g}$ in humans. Meanwhile, NAM methylation may be counter-balanced by conversion of NAM to NMN, a reaction mediated by Nampt, which has a low $\mathrm{K}_{\mathrm{M}}$ for NAM (5 nM [132]). Therefore, at the initial stages of increased NAM in cells, NMN conversion would be dominant over NAM methylation, although this might be an overstatement considering that the $\mathrm{K}_{\mathrm{M}}$ of Nampt increases nearly 20-fold in the presence of $\mathrm{NAD}^{+}$[133]. Overall, further studies are warranted to analyze the effects of NAM on cellular expression of genes and activities of proteins.

\subsection{High-Level NAM Methylation: Potential Adverse Effects of Altered Methyl Pool}

High levels of NNMT expression and metNAM concentration are reported to be involved in certain diseases and conditions such as obesity, type-2 diabetes, hepatotoxicity, Parkinson's disease, and cancers (summarized in Figure 2). Therefore, NAM administration raises concerns as an etiologic factor for these pathological conditions. However, it is not clear whether common mechanisms underlie the different conditions.

\subsubsection{Insulin Resistance and Metabolic Syndrome}

NAM treatment caused a significant decrease in insulin sensitivity in human subjects $(2 \mathrm{~g} /$ day for 2 weeks) [45] and in animals ( 1 or $4 \mathrm{~g} / \mathrm{kg}$ for 8 weeks) [94,134]. Direct involvement of metNAM in insulin resistance was suggested. Administration of either NAM or metNAM to healthy rats led to an increase in the levels of glucose and insulin [134]. In addition, inhibition of NNMT activity, and thereby reduction of plasma metNAM level, reduced body weight and improved inulin sensitivity of obese mice fed a high-fat diet [135]. The mechanism by which metNAM induces insulin resistance is poorly understood. An effect of oxidative stress is considered. High-level metNAM increased plasma level of $\mathrm{H} 2 \mathrm{O} 2$ [134], and metNAM, but not NAM, triggered oxidative stress in C. elegans [136]. Meanwhile, NNMT, in production of metNAM, also produces S-adenosylhomocysteine, which is a precursor of homocysteine [137] (Figure 2). Positive associations have been reported between increased plasma level of homocysteine and insulin resistance as well as cardiovascular disease [138-141]. Elevated level of homocysteine leads to insulin resistance by increasing production of interleukin-6 (IL-6) [142], a suppressor of insulin signaling [143] and by inducing endoplasmic reticulum stress [144], a trigger of insulin resistance [145]. Therefore, metNAM itself or a hyper-methyl metabolism process driven by high-level NAM may be the cause of increased insulin resistance.

\subsubsection{Parkinson's Disease}

Brain cells demand high levels of bioenergetics and are heavily dependent on the salvage pathway for $\mathrm{NAD}^{+}$supply [5]. For this reason, NAM administration is considered to be protective for neuron viability and brain function [27]. For Parkinson's disease (PD) (and other brain diseases), beneficial effects have been observed. NAM treatment protected dopaminergic neurons and sustained striatal 
dopamine level in a mouse model of PD [3]. Further, the treatment improved locomotor activity and attenuated dopamine depletion in a mouse model [146]. These outcomes are proposed to be driven by NAM-mediated increase in the level of NADH, a cofactor necessary for dopamine biosynthesis and a reducing power for glutathione that is generally insufficient in PD [147]. Additionally, increased activities of SIRT1 and SIRT3 would exert important positive effects for mitochondrial integrity and function, thereby stabilizing energy homeostasis. However, NAM metabolism has also been linked to neurotoxicity and PD. NAM treatment at $500 \mathrm{mg} / \mathrm{kg}$ increased the rate of motor decline and induced development of behavioral deficits in PD rats [114]. Importantly, the levels of both NNMT and metNAM are elevated in the brain of PD patients [148,149]. MetNAM was suggested to induce ROS production by inhibiting mitochondrial complex I, which is subsequently destroyed by ROS [150,151]. Hence, mitochondrial dysfunction by metNAM has been proposed as an etiology of PD. However, a recent study found that metNAM does not affect complex I activity, although it does produce ROS [136]. In that study, metNAM functioned positively in extending nematode life span. Therefore, neither the effect nor the mechanism of PD deterioration by NAM is clear and requires closer analyses. On the other hand, preconception of NAM as an inhibitor to sirtuin proteins might contribute to the lack of understanding. A recent study on SIRT1 activation in a mouse model of Huntington's disease reported that resveratrol attenuated a decline in mitochondrial function and improved motor coordination and learning. NAM, which was adopted in that study as an inhibitor of SIRT1, was reported to block mitochondria-related transcription and worsen motor phenotypes [9]. However, data on such negative effects of NAM were inconsistent with assays that showed NAM treatment to has effects similar to those of resveratrol. In addition, the dose of NAM may not be high enough to produce effects as positive as those of resveratrol.

\subsubsection{Cardiac Diseases}

Serum levels of metNAM and NNMT activity are associated with severity of coronary artery disease (CAD) in human patients [152]. Poor mitochondrial function has been causatively linked to heart failure and CAD; therefore, an adverse effect on mitochondrial function could be linked to CAD [153]. metNAM-mediated increases in ROS and mitochondrial dysfunction could be possible mechanisms [150], although this seems improbable or incomplete, as described for PD above. On the other hand, a high level of homocysteine is a risk factor for CAD [154]; therefore, methyl metabolism, rather than metNAM per se, could be linked to CAD. Meanwhile, nicotinamide riboside (NR), another $\mathrm{NAD}^{+}$precursor, has been shown to effectively protect the heart while preserving mitochondrial ultrastructure and reducing ROS and cardiomyocyte death $[155,156]$, suggesting a cardio-protective effect of high-level NAD ${ }^{+}$. The finding that NR treatment increases the level of metNAM (by more than 10-fold compared to NAM-induced increase in marginal level) [156] could rule out an adverse effect of metNAM per se.

\subsubsection{Liver Toxicity}

High doses of NAM showed hepatotoxicity in humans and rats [47,112]. The liver is the organ that expresses NNMT at the highest level [157] and may therefore be more sensitive to high concentrations of NAM. ROS-independent mechanisms have been proposed for hepatotoxicity. A dose-dependent decrease in the level of DNA methylation was observed in the liver cells of rats given dietary supplementation of NAM at a dose of $1 \mathrm{~g} / \mathrm{kg}$ [94], suggesting interference in cellular methyl metabolism. Meanwhile, NAM fed alongside a high-fat diet caused fatty liver deterioration in mice overexpressing NNMT [113]. NNMT over-activation lowered hepatic NAD ${ }^{+}$content and decreased SIRT3 activity, and thereby, inhibiting the expression of genes related to fatty acid oxidation. However, this is not expected to occur in cases of NAM treatment. The same study also showed increased expression of the connective tissue growth factor (CTGF) gene through a decrease in methylation of the promoter, and this might be related to liver steatosis and fibrosis. Meanwhile, NAM administration was well tolerated in more recent studies, which generally used purer preparations of NAM [121]. This suggests 
that hepatic abnormality rather than toxicity might originate from NA [158] that was present as a contaminant, but this possibility has not been carefully addressed. Meanwhile, there are studies reporting NAM's protective effect against hepatotoxicity caused by alcohol [159]. Ethanol increases the cellular NADH/NAD ${ }^{+}$ratio, and NAM may counterbalance this by increasing $\mathrm{NAD}^{+}$level.

\subsection{Potential Positive Effects of metNAM: Contradiction to the Proposed Adverse Effects}

In men experiencing an energy deficit, metNAM level in circulation is increased through elevated NNMT expression and stimulated lipolysis [160]. This suggests that enhanced fat utilization in low-energy conditions is facilitated by metNAM. In cultures of human myotubes, metNAM was secreted and stimulated lipolysis without affecting the level of glucagon or insulin secretion [160]. Therefore, metNAM is proposed to function as a myokine that enhances utilization of energy stores. This is a contradiction to the observation of metNAM-induced obesity or metabolic syndrome [152,161]. In addition, both NAM and metNAM expanded the life span of C. elegans even in the absence of sir-2.1, a worm homologue of SIRT1 [136]. metNAM is a substrate of aldehyde oxidase in cytochrome P450 in generation of $\mathrm{H}_{2} \mathrm{O}_{2}$, which may act as mitohormetic ROS that promote longevity in worms. In this case, metNAM is viewed to produce ROS at levels suitable for mitochondrial function. Furthermore, a direct effect of metNAM on SIRT1 has been suggested. Supplementation of a high-fat diet with metNAM decreases serum and liver cholesterol and liver triglyceride levels in mice. In addition, MetNAM stabilizes the SIRT1 protein and enhances deacetylation of SIRT1 targets. Protection of SIRT1 from proteasome-mediated degradation by metNAM has been suggested [162]. Decreased synthesis of triglycerides and cholesterol in hepatocytes, and thereby amelioration of fatty liver, by high-level metNAM were also reported [163].

Meanwhile, intravenous treatment of rats with metNAM at 3-100 mg/kg, but not of NAM, exerted a sustained thrombolytic effect mediated by elevated synthesis of prostacyclin, a vasodilator, by cyclooxygenase-2 activation [164].

\subsection{N-Methyl-2-Pyridone-5-Carboxamide: A Potential Uremic Toxin}

MetNAM is degraded to 2-PY and 4-PY, which are excreted through urine [48]. 2-PY is a major species in urine after intake of NAM or NA [165]. However, it is retained in renal failure patients and thereby classified as a uremic toxin [166]. The toxicity has been presumed to be attributed to PARP inhibition [167], but there is lack of evidence. 2-PY has drawn attention since its level was found to be elevated upon NAM administration to treat hyperphosphatemia, which is a chronic, toxic retention of inorganic phosphorus (Pi) in the blood of chronic kidney disease (CKD) patients [49,87]. NAM treatment alleviates hyperphosphatemia by increasing renal and fecal Pi excretion [88,89]. Meanwhile, 2-PY does not appear to be toxic in individuals without renal dysfunction. In a study of a large group of skin cancer patients treated with NAM at $500 \mathrm{mg}$ twice daily for 5 years, no cases of renal dysfunction or uremic toxicity were reported [168].

\section{Concluding Remarks and Perspectives}

Despite numerous studies on the beneficial effects of NAM, not many clinical applications have been made. A reason for this is likely the marginal efficacy of NAM as a therapeutic agent or medicine as compared to drugs targeting specific enzymes. It is rather expected to be more effective against age-associated conditions considering the decline of $\mathrm{NAD}^{+}$levels, sirtuin activities, and mitochondrial quality with aging. In addition, attenuation of ROS generation by NAM can be beneficial in preventing ageing-associated degenerative diseases. These advocate NAM's usefulness as a long term supplementation. For this reason, any adverse effects of NAM should be disclosed and their molecular mechanisms should be understood. As summarized in Table 2, adverse effects reported for humans are limited to several organs, namely liver, kidney, and cells in plasma. Pancreatic $\beta$-cells might also be affected. However, as described, concerns based on cell biological studies for the potential adverse effects of NAM are not limited to those caused by direct inhibition of PARPs (and 
other ADP-ribosyltransferases). Subsequent changes in $\mathrm{NAD}^{+}$redox as well as the levels of $\mathrm{NAD}^{+}$ and NAM metabolites are possible causes of concern, especially for cases of long-term use of NAM.

This review suggests some points for the direction of prospective studies on the clinical and supplementary usage of NAM. First, effect of NAM on diabetes has been controversial. Both an improvement in $\beta$-cell function and a reduction in insulin sensitivity were reported in human studies (Table 2). NAM is still an attractive candidate in the regimen against diabetes, and so conclusive researches need to be made on the effectiveness of NAM on diabetes. Second, although most of the reported adverse effects of NAM resolved upon termination of use [169], extended or life-long use poses a potential threat of irreversible conditions such as carcinogenesis, PD, and type 2 diabetes. In this regard, follow-up with subjects of previous long-term studies such as ENDIT would provide valuable information. Third, there may be issues that cannot be resolved by such retrospective studies. Although life-long NAM supplementation did not produce cancer, it promoted carcinogen-induced tumorigenesis in rats. Furthermore, NAM supplementation to pregnant rats caused changes in the patterns of DNA methylation and mRNA expression in fetal organs [170]. These studies warrant careful examination of the genetic and epigenetic effects of NAM treatment. Fourth, more human studies are demanded. Most of these reported adverse effects occur only in doses higher than those used clinically or for daily dietary supplementation. The reported effects on animals occur with doses at least 10-fold higher than the highest used in human subjects, a $3 \mathrm{~g} /$ day dietary intake. Therefore, these adverse conditions and outcomes are not expected to be induced by general pharmaceutical or therapeutic doses of NAM. Still, there exist differences in model animals and humans not only in life span and life style but also in drug metabolism. For example, rodents and humans have different circadian rhythms, which affect NAM-NAD ${ }^{+}$metabolism differently [171]. These certainly make it difficult to predict the effects of NAM through simple extrapolation of animal studies. Another factor that calls for more studies on human subjects is individual- and age-related variations in pharmacogenetics of NAM metabolism. For example, the enzymatic activity of NNMT in humans varies over five-fold likely due to epigenetic polymorphism [172]. Therefore, understanding on pharmacogenetics and pharmacoepigenetics of the enzymes involved in NAM-NAD ${ }^{+}$metabolism should accompany the studies on NAM's efficacies.

Finally, a number of clinical trials on $\mathrm{NAD}^{+}$precursors, i.e., NAM riboside (NR) and nicotinamide mononucleotide (NMN), have been completed or are ongoing [ABOUTNAD (https://www.aboutnad. com/human-clinical-trials)]. Comprehensive understanding of the effects of these chemicals and NAM would produce invaluable information regarding a life-long application of these $\mathrm{NAD}^{+}$precursors.

Author Contributions: S.B.S. searched and analyzed literature and prepared the tables. E.S.H. conceived the study, analyzed the literature, and wrote the manuscript. All authors have read and agreed to the published version of the manuscript.

Funding: This research received no external funding.

Conflicts of Interest: The authors declare no conflict of interest.

\section{References}

1. Elvehjem, C.A.; Madden, R.J.; Strong, F.M.; Wolley, D.W. The isolation and identification of the anti-black tongue factor. J. Biol. Chem. 1938, 123, 137-149. [CrossRef] [PubMed]

2. Yang, J.; Klaidman, L.K.; Nalbandian, A.; Oliver, J.; Chang, M.L.; Chan, P.H.; Adams, J.D., Jr. The effects of nicotinamide on energy metabolism following transient focal cerebral ischemia in wistar rats. Neurosci. Lett. 2002, 333, 91-94. [CrossRef]

3. Anderson, D.W.; Bradbury, K.A.; Schneider, J.S. Broad neuroprotective profile of nicotinamide in different mouse models of mptp-induced parkinsonism. Eur. J. Neurosci. 2008, 28, 610-617. [CrossRef] [PubMed]

4. Mokudai, T.; Ayoub, I.A.; Sakakibara, Y.; Lee, E.J.; Ogilvy, C.S.; Maynard, K.I. Delayed treatment with nicotinamide (vitamin $\mathrm{b}(3)$ ) improves neurological outcome and reduces infarct volume after transient focal cerebral ischemia in wistar rats. Stroke 2000, 31, 1679-1685. [CrossRef] [PubMed] 
5. Wang, P.; Miao, C.Y. Nampt as a therapeutic target against stroke. Trends Pharmacol. Sci. 2015, 36, 891-905. [CrossRef]

6. Sheline, C.T.; Cai, A.L.; Zhu, J.; Shi, C. Serum or target deprivation-induced neuronal death causes oxidative neuronal accumulation of $\mathrm{zn}^{2+}$ and loss of nad+. Eur. J. Neurosci. 2010, 32, 894-904. [CrossRef]

7. Cai, A.L.; Zipfel, G.J.; Sheline, C.T. Zinc neurotoxicity is dependent on intracellular nad levels and the sirtuin pathway. Eur. J. Neurosci. 2006, 24, 2169-2176. [CrossRef]

8. Hathorn, T.; Snyder-Keller, A.; Messer, A. Nicotinamide improves motor deficits and upregulates pgc-1alpha and bdnf gene expression in a mouse model of huntington's disease. Neurobiol. Dis. 2011, 41, 43-50. [CrossRef]

9. Naia, L.; Rosenstock, T.R.; Oliveira, A.M.; Oliveira-Sousa, S.I.; Caldeira, G.L.; Carmo, C.; Laco, M.N.; Hayden, M.R.; Oliveira, C.R.; Rego, A.C. Comparative mitochondrial-based protective effects of resveratrol and nicotinamide in huntington's disease models. Mol. Neurobiol. 2017, 54, 5385-5399. [CrossRef]

10. Green, K.N.; Steffan, J.S.; Martinez-Coria, H.; Sun, X.; Schreiber, S.S.; Thompson, L.M.; LaFerla, F.M. Nicotinamide restores cognition in alzheimer's disease transgenic mice via a mechanism involving sirtuin inhibition and selective reduction of thr231-phosphotau. J. Neurosci. 2008, 28, 11500-11510. [CrossRef]

11. Bold, J.M.; Gardner, C.R.; Walker, R.J. Central effects of nicotinamide and inosine which are not mediated through benzodiazepine receptors. Br. J. Pharmacol. 1985, 84, 689-696. [CrossRef] [PubMed]

12. Hiromatsu, Y.; Sato, M.; Yamada, K.; Nonaka, K. Inhibitory effects of nicotinamide on recombinant human interferon-gamma-induced intercellular adhesion molecule-1 (icam-1) and hla-dr antigen expression on cultured human endothelial cells. Immunol. Lett. 1992, 31, 35-39. [CrossRef]

13. Ferreira, R.G.; Matsui, T.C.; Godin, A.M.; Gomides, L.F.; Pereira-Silva, P.E.; Duarte, I.D.; Menezes, G.B.; Coelho, M.M.; Klein, A. Neutrophil recruitment is inhibited by nicotinamide in experimental pleurisy in mice. Eur. J. Pharmacol. 2012, 685, 198-204. [CrossRef]

14. Miesel, R.; Kurpisz, M.; Kroger, H. Modulation of inflammatory arthritis by inhibition of poly(adp ribose) polymerase. Inflammation 1995, 19, 379-387. [CrossRef] [PubMed]

15. Snaidr, V.A.; Damian, D.L.; Halliday, G.M. Nicotinamide for photoprotection and skin cancer chemoprevention: A review of efficacy and safety. Exp. Dermatol. 2019, 28 (Suppl. 1), 15-22. [CrossRef] [PubMed]

16. Murray, M.F. Nicotinamide: An oral antimicrobial agent with activity against both mycobacterium tuberculosis and human immunodeficiency virus. Clin. Infect. Dis. 2003, 36, 453-460. [CrossRef]

17. Murray, M.F.; Srinivasan, A. Nicotinamide inhibits hiv-1 in both acute and chronic in vitro infection. Biochem. Biophys. Res. Commun. 1995, 210, 954-959. [CrossRef]

18. Crino, A.; Schiaffini, R.; Manfrini, S.; Mesturino, C.; Visalli, N.; Beretta Anguissola, G.; Suraci, C.; Pitocco, D.; Spera, S.; Corbi, S.; et al. A randomized trial of nicotinamide and vitamin e in children with recent onset type 1 diabetes (imdiab ix). Eur. J. Endocrinol. 2004, 150, 719-724. [CrossRef]

19. Elliott, R.B.; Pilcher, C.C.; Fergusson, D.M.; Stewart, A.W. A population based strategy to prevent insulin-dependent diabetes using nicotinamide. J. Pediatric Endocrinol. Metab. 1996, 9, 501-509. [CrossRef]

20. Gale, E.A.; Bingley, P.J.; Emmett, C.L.; Collier, T.; European Nicotinamide Diabetes Intervention Trial Group. European nicotinamide diabetes intervention trial (endit): A randomised controlled trial of intervention before the onset of type 1 diabetes. Lancet 2004, 363, 925-931. [CrossRef]

21. Staeva-Vieira, T.; Peakman, M.; von Herrath, M. Translational mini-review series on type 1 diabetes: Immune-based therapeutic approaches for type 1 diabetes. Clin. Exp. Immunol. 2007, 148, 17-31. [CrossRef]

22. Maes, M.; Galecki, P.; Chang, Y.S.; Berk, M. A review on the oxidative and nitrosative stress (o\&ns) pathways in major depression and their possible contribution to the (neuro)degenerative processes in that illness. Prog. Neuro-Psychopharmacol. Biol. Psychiatry 2011, 35, 676-692.

23. Hollis, F.; van der Kooij, M.A.; Zanoletti, O.; Lozano, L.; Canto, C.; Sandi, C. Mitochondrial function in the brain links anxiety with social subordination. Proc. Natl. Acad. Sci. USA 2015, 112, 15486-15491. [CrossRef]

24. Dedee, F.; Murrell, M.R.-Q. Management and Prognosis of Bullous Pemphigoid. 2019. Available online: https://www.uptodate.com/contents/management-and-prognosis-of-bullous-pemphigoid (accessed on 23 April 2020).

25. Starr, P. Oral nicotinamide prevents common skin cancers in high-risk patients, reduces costs. Am. Health Drug. Benefits 2015, 8, 13-14. [PubMed] 
26. Damian, D.L.; Patterson, C.R.; Stapelberg, M.; Park, J.; Barnetson, R.S.; Halliday, G.M. Uv radiation-induced immunosuppression is greater in men and prevented by topical nicotinamide. J. Investig. Dermatol. 2008, 128, 447-454. [CrossRef] [PubMed]

27. Song, S.B.; Park, J.S.; Chung, G.J.; Lee, I.H.; Hwang, E.S. Diverse therapeutic efficacies and more diverse mechanisms of nicotinamide. Metabolomics 2019, 15, 137. [CrossRef] [PubMed]

28. Prousky, J. Vitamin b3 for depression: Case report and review of the literature. J. Orthomol. Med. 2010, 25, 137-147.

29. Saini, J.S.; Corneo, B.; Miller, J.D.; Kiehl, T.R.; Wang, Q.; Boles, N.C.; Blenkinsop, T.A.; Stern, J.H.; Temple, S. Nicotinamide ameliorates disease phenotypes in a human ipsc model of age-related macular degeneration. Cell Stem Cell 2017, 20, 635-647.e7. [CrossRef]

30. Williams, P.A.; Harder, J.M.; Foxworth, N.E.; Cardozo, B.H.; Cochran, K.E.; John, S.W.M. Nicotinamide and wld(s) act together to prevent neurodegeneration in glaucoma. Front. Neurosci. 2017, 11, 232. [CrossRef]

31. Williams, P.A.; Harder, J.M.; John, S.W.M. Glaucoma as a metabolic optic neuropathy: Making the case for nicotinamide treatment in glaucoma. J. Glaucoma 2017, 26, 1161-1168. [CrossRef]

32. Nakajima, H.; Yamada, K.; Hanafusa, T.; Fujino-Kurihara, H.; Miyagawa, J.; Miyazaki, A.; Saitoh, R.; Minami, Y.; Kono, N.; Nonaka, K.; et al. Elevated antibody-dependent cell-mediated cytotoxicity and its inhibition by nicotinamide in the diabetic nod mouse. Immunol. Lett. 1986, 12, 91-94. [CrossRef]

33. Monfrecola, G.; Gaudiello, F.; Cirillo, T.; Fabbrocini, G.; Balato, A.; Lembo, S. Nicotinamide downregulates gene expression of interleukin-6, interleukin-10, monocyte chemoattractant protein-1, and tumour necrosis factor-alpha gene expression in hacat keratinocytes after ultraviolet b irradiation. Clin. Exp. Dermatol. 2013, 38, 185-188. [CrossRef] [PubMed]

34. Nagai, A.; Matsumiya, H.; Hayashi, M.; Yasui, S.; Okamoto, H.; Konno, K. Effects of nicotinamide and niacin on bleomycin-induced acute injury and subsequent fibrosis in hamster lungs. Exp. Lung Res. 1994, 20, 263-281. [CrossRef] [PubMed]

35. Gurujeyalakshmi, G.; Iyer, S.N.; Hollinger, M.A.; Giri, S.N. Procollagen gene expression is down-regulated by taurine and niacin at the transcriptional level in the bleomycin hamster model of lung fibrosis. J. Pharmacol. Exp. Ther. 1996, 277, 1152-1157.

36. Kim, S.K.; Yun, S.J.; Kim, J.; Lee, O.J.; Bae, S.C.; Kim, W.J. Identification of gene expression signature modulated by nicotinamide in a mouse bladder cancer model. PLoS ONE 2011, 6, e26131. [CrossRef] [PubMed]

37. Kim, W.J.; Lee, J.W.; Quan, C.; Youn, H.J.; Kim, H.M.; Bae, S.C. Nicotinamide inhibits growth of carcinogen induced mouse bladder tumor and human bladder tumor xenograft through up-regulation of runx3 and p300. J. Urol. 2011, 185, 2366-2375. [CrossRef]

38. Omidian, M.; Khazanee, A.; Yaghoobi, R.; Ghorbani, A.R.; Pazyar, N.; Beladimousavi, S.S.; Ghadimi, M.; Mohebbipour, A.; Feily, A. Therapeutic effect of oral nicotinamide on refractory uremic pruritus: A randomized, double-blind study. Saudi J. Kidney Dis. Transplant. 2013, 24, 995-999.

39. Pozzilli, P.; Visalli, N.; Buzzetti, R.; Cavallo, M.G.; Marietti, G.; Hawa, M.; Leslie, R.D. Metabolic and immune parameters at clinical onset of insulin-dependent diabetes: A population-based study. Imdiab study group. Immunotherapy diabetes. Metabolism 1998, 47, 1205-1210. [CrossRef]

40. Kalckar, H.M.; Maxwell, E.S.; Strominger, J.L. Some properties of uridine diphosphoglucose dehydrogenase. Arch. Biochem. Biophys. 1956, 65, 2-10.

41. Muller, D.; Mehling, H.; Otto, B.; Bergmann-Lips, R.; Luft, F.; Jordan, J.; Kettritz, R. Niacin lowers serum phosphate and increases hdl cholesterol in dialysis patients. Clin. J. Am. Soc. Nephrol. 2007, 2, 1249-1254. [CrossRef]

42. Surjana, D.; Halliday, G.M.; Martin, A.J.; Moloney, F.J.; Damian, D.L. Oral nicotinamide reduces actinic keratoses in phase ii double-blinded randomized controlled trials. J. Investig. Dermatol. 2012, 132, 1497-1500. [CrossRef] [PubMed]

43. Horsman, M.R.; Hoyer, M.; Honess, D.J.; Dennis, I.F.; Overgaard, J. Nicotinamide pharmacokinetics in humans and mice: A comparative assessment and the implications for radiotherapy. Radiother. Oncol. 1993, 27, 131-139. [CrossRef]

44. Hoffer, A. Biochemistry of nicotinic acid and nicotinamide. Psychosomatics 1967, 8, 95-100. [CrossRef]

45. Greenbaum, C.J.; Kahn, S.E.; Palmer, J.P. Nicotinamide's effects on glucose metabolism in subjects at risk for iddm. Diabetes 1996, 45, 1631-1634. [CrossRef] 
46. Hwang, E.S.; Song, S.B. Nicotinamide is an inhibitor of sirt1 in vitro, but can be a stimulator in cells. Cell. Mol. Life Sci. 2017, 74, 3347-3362. [CrossRef] [PubMed]

47. Winter, S.L.; Boyer, J.L. Hepatic toxicity from large doses of vitamin b3 (nicotinamide). N. Engl. J. Med. 1973, 289, 1180-1182. [CrossRef]

48. Lenglet, A.; Liabeuf, S.; Bodeau, S.; Louvet, L.; Mary, A.; Boullier, A.; Lemaire-Hurtel, A.S.; Jonet, A.; Sonnet, P.; Kamel, S.; et al. N-methyl-2-pyridone-5-carboxamide (2py)-major metabolite of nicotinamide: An update on an old uremic toxin. Toxins (Basel) 2016, 8, 339. [CrossRef]

49. Lenglet, A.; Liabeuf, S.; Esper, N.E.; Brisset, S.; Mansour, J.; Lemaire-Hurtel, A.S.; Mary, A.; Brazier, M.; Kamel, S.; Mentaverri, R.; et al. Efficacy and safety of nicotinamide in haemodialysis patients: The nicoren study. Nephrol. Dial. Transplant. 2017, 32, 1597. [CrossRef]

50. Jiao, X.; Doamekpor, S.K.; Bird, J.G.; Nickels, B.E.; Tong, L.; Hart, R.P.; Kiledjian, M. 5' end nicotinamide adenine dinucleotide cap in human cells promotes rna decay through dxo-mediated denadding. Cell 2017, 168, 1015-1027.e10. [CrossRef]

51. Zhou, S.S.; Li, D.; Zhou, Y.M.; Sun, W.P.; Liu, Q.G. B-vitamin consumption and the prevalence of diabetes and obesity among the us adults: Population based ecological study. BMC Public Health 2010, 10, 746. [CrossRef]

52. Bonkowski, M.S.; Sinclair, D.A. Slowing ageing by design: The rise of nad(+) and sirtuin-activating compounds. Nat. Rev. Mol. Cell Biol. 2016, 17, 679-690. [CrossRef] [PubMed]

53. Hasmann, M.; Schemainda, I. Fk866, a highly specific noncompetitive inhibitor of nicotinamide phosphoribosyltransferase, represents a novel mechanism for induction of tumor cell apoptosis. Cancer Res. 2003, 63, 7436-7442. [PubMed]

54. Ghosh, D.; LeVault, K.R.; Barnett, A.J.; Brewer, G.J. A reversible early oxidized redox state that precedes macromolecular ros damage in aging nontransgenic and 3xtg-ad mouse neurons. J. Neurosci. 2012, 32, 5821-5832. [CrossRef] [PubMed]

55. Song, S.B.; Jang, S.Y.; Kang, H.T.; Wei, B.; Jeoun, U.W.; Yoon, G.S.; Hwang, E.S. Modulation of mitochondrial membrane potential and ros generation by nicotinamide in a manner independent of sirt1 and mitophagy. Mol. Cells 2017, 40, 503-514.

56. Aman, Y.; Qiu, Y.; Tao, J.; Fang, E.F. Therapeutic potential of boosting nad + in aging and age-related diseases. Transl. Med. Aging 2018, 2, 30-37. [CrossRef]

57. Scialo, F.; Fernandez-Ayala, D.J.; Sanz, A. Role of mitochondrial reverse electron transport in ros signaling: Potential roles in health and disease. Front. Physiol. 2017, 8, 428. [CrossRef]

58. Carafa, V.; Rotili, D.; Forgione, M.; Cuomo, F.; Serretiello, E.; Hailu, G.S.; Jarho, E.; Lahtela-Kakkonen, M.; Mai, A.; Altucci, L. Sirtuin functions and modulation: From chemistry to the clinic. Clin. Epigenet. 2016, 8, 61. [CrossRef]

59. Klotz, L.O.; Sanchez-Ramos, C.; Prieto-Arroyo, I.; Urbanek, P.; Steinbrenner, H.; Monsalve, M. Redox regulation of foxo transcription factors. Redox Biol. 2015, 6, 51-72. [CrossRef]

60. Qiu, X.; Brown, K.; Hirschey, M.D.; Verdin, E.; Chen, D. Calorie restriction reduces oxidative stress by sirt3-mediated sod2 activation. Cell Metab. 2010, 12, 662-667. [CrossRef]

61. Tao, R.; Coleman, M.C.; Pennington, J.D.; Ozden, O.; Park, S.H.; Jiang, H.; Kim, H.S.; Flynn, C.R.; Hill, S.; Hayes McDonald, W.; et al. Sirt3 Cell Metab-mediated deacetylation of evolutionarily conserved lysine 122 regulates mnsod activity in response to stress. Mol. Cell 2010, 40, 893-904. [CrossRef]

62. Hafner, A.V.; Dai, J.; Gomes, A.P.; Xiao, C.Y.; Palmeira, C.M.; Rosenzweig, A.; Sinclair, D.A. Regulation of the mptp by sirt3-mediated deacetylation of cypd at lysine 166 suppresses age-related cardiac hypertrophy. Aging (Albany NY) 2010, 2, 914-923. [CrossRef] [PubMed]

63. Chong, Z.Z.; Lin, S.H.; Maiese, K. Nicotinamide modulates mitochondrial membrane potential and cysteine protease activity during cerebral vascular endothelial cell injury. J. Vasc. Res. 2002, 39, 131-147. [CrossRef] [PubMed]

64. Lin, S.H.; Chong, Z.Z.; Maiese, K. Nicotinamide: A nutritional supplement that provides protection against neuronal and vascular injury. J. Med. Food 2001, 4, 27-38. [CrossRef] [PubMed]

65. Kang, H.T.; Lee, H.I.; Hwang, E.S. Nicotinamide extends replicative lifespan of human cells. Aging Cell 2006, 5, 423-436. [CrossRef] [PubMed]

66. Jang, S.Y.; Kang, H.T.; Hwang, E.S. Nicotinamide-induced mitophagy: Event mediated by high nad+/nadh ratio and sirt1 protein activation. J. Biol. Chem. 2012, 287, 19304-19314. [CrossRef] [PubMed] 
67. Kang, H.T.; Hwang, E.S. Nicotinamide enhances mitochondria quality through autophagy activation in human cells. Aging Cell 2009, 8, 426-438. [CrossRef] [PubMed]

68. Ok, J.S.; Song, S.B.; Hwang, E.S. Enhancement of replication and differentiation potential of human bone marrow stem cells by nicotinamide treatment. Int. J. Stem Cells 2018, 11, 13-25. [CrossRef]

69. Berger, N.A. Poly(adp-ribose) in the cellular response to DNA damage. Radiat. Res. 1985, 101, 4-15. [CrossRef]

70. Zhang, J.; Dawson, V.L.; Dawson, T.M.; Snyder, S.H. Nitric oxide activation of poly(adp-ribose) synthetase in neurotoxicity. Science 1994, 263, 687-689. [CrossRef]

71. Ying, W.; Garnier, P.; Swanson, R.A. Nad+ repletion prevents parp-1-induced glycolytic blockade and cell death in cultured mouse astrocytes. Biochem. Biophys. Res. Commun. 2003, 308, 809-813. [CrossRef]

72. Zong, W.X.; Ditsworth, D.; Bauer, D.E.; Wang, Z.Q.; Thompson, C.B. Alkylating DNA damage stimulates a regulated form of necrotic cell death. Genes Dev. 2004, 18, 1272-1282. [CrossRef] [PubMed]

73. Pazzaglia, S.; Pioli, C. Multifaceted role of parp-1 in DNA repair and inflammation: Pathological and therapeutic implications in cancer and non-cancer diseases. Cells 2019, 9, 41. [CrossRef] [PubMed]

74. Hoffer, A. Treatment of arthritis by nicotinic acid and nicotinamide. Can. Med. Assoc. J. 1959, 81, $235-238$. [PubMed]

75. William, K. The Common form of Joint Dysfunction: Its Incidence and Treatment; E. L. Hildreth \& Company: Brattleboro, VT, USA, 1949.

76. Namazi, M.R. Nicotinamide: A potential addition to the anti-psoriatic weaponry. FASEB J. 2003, 17, 1377-1379. [CrossRef] [PubMed]

77. Hassan, N.; Janjua, M.Z. The optimum dose of nicotinamide for protection of pancreatic beta-cells against the cytotoxic effect of streptozotocin in albino rat. J. Ayub Med. Coll. Abbottabad 2001, 13, 26-30.

78. Kolb, H.; Burkart, V. Nicotinamide in type 1 diabetes. Mechanism of action revisited. Diabetes Care 1999, 22 (Suppl. 2), B16-B20.

79. Purushotham, A.; Schug, T.T.; Xu, Q.; Surapureddi, S.; Guo, X.; Li, X. Hepatocyte-specific deletion of sirt1 alters fatty acid metabolism and results in hepatic steatosis and inflammation. Cell Metab. 2009, 9, 327-338. [CrossRef]

80. Rodgers, J.T.; Lerin, C.; Haas, W.; Gygi, S.P.; Spiegelman, B.M.; Puigserver, P. Nutrient control of glucose homeostasis through a complex of pgc-1alpha and sirt1. Nature 2005, 434, 113-118. [CrossRef]

81. Ahn, J.; Cho, I.; Kim, S.; Kwon, D.; Ha, T. Dietary resveratrol alters lipid metabolism-related gene expression of mice on an atherogenic diet. J. Hepatol. 2008, 49, 1019-1028. [CrossRef]

82. Jeong, J.; Juhn, K.; Lee, H.; Kim, S.H.; Min, B.H.; Lee, K.M.; Cho, M.H.; Park, G.H.; Lee, K.H. Sirt1 promotes DNA repair activity and deacetylation of ku70. Exp. Mol. Med. 2007, 39, 8-13. [CrossRef]

83. Gillum, M.P.; Kotas, M.E.; Erion, D.M.; Kursawe, R.; Chatterjee, P.; Nead, K.T.; Muise, E.S.; Hsiao, J.J.; Frederick, D.W.; Yonemitsu, S.; et al. Sirt1 regulates adipose tissue inflammation. Diabetes 2011, 60, 3235-3245. [CrossRef] [PubMed]

84. Hori, Y.S.; Kuno, A.; Hosoda, R.; Horio, Y. Regulation of foxos and p53 by sirt1 modulators under oxidative stress. PLoS ONE 2013, 8, e73875. [CrossRef] [PubMed]

85. Guarente, L. Calorie restriction and sirtuins revisited. Genes Dev. 2013, 27, 2072-2085. [CrossRef] [PubMed]

86. Dong, Y.J.; Liu, N.; Xiao, Z.; Sun, T.; Wu, S.H.; Sun, W.X.; Xu, Z.G.; Yuan, H. Renal protective effect of sirtuin 1. J. Diabetes Res. 2014, 2014, 843786. [CrossRef]

87. Delmez, J.A.; Slatopolsky, E. Hyperphosphatemia: Its consequences and treatment in patients with chronic renal disease. Am. J. Kidney Dis. 1992, 19, 303-317. [CrossRef]

88. Thomas, P.; Dousa, S.A.K. Role of nicotinamide adenine dinucleotide (nad) in control of proximal renal tubular phosphate transport. In Urolithiasis; Springer: Boston, MA, USA, 1981; pp. 741-745.

89. Eto, N.; Miyata, Y.; Ohno, H.; Yamashita, T. Nicotinamide prevents the development of hyperphosphataemia by suppressing intestinal sodium-dependent phosphate transporter in rats with adenine-induced renal failure. Nephrol. Dial. Transplant. 2005, 20, 1378-1384. [CrossRef]

90. Rennie, G.; Chen, A.C.; Dhillon, H.; Vardy, J.; Damian, D.L. Nicotinamide and neurocognitive function. Nutr. Neurosci. 2015, 18, 193-200. [CrossRef]

91. Slominski, A.; Semak, I.; Pisarchik, A.; Sweatman, T.; Szczesniewski, A.; Wortsman, J. Conversion of 1-tryptophan to serotonin and melatonin in human melanoma cells. FEBS Lett. 2002, 511, 102-106. [CrossRef]

92. McCarty, M.F. High-dose pyridoxine as an 'anti-stress' strategy. Med. Hypotheses 2000, 54, 803-807. [CrossRef] 
93. Unilever. Niacinamide: Safety Assessment (Document Number d97/059), Section 5; Safety Assessment of Topically Applied Niacinamide; CTFA (Personal Care Products Council): Washington, DC, USA, 1998.

94. Li, D.; Tian, Y.J.; Guo, J.; Sun, W.P.; Lun, Y.Z.; Guo, M.; Luo, N.; Cao, Y.; Cao, J.M.; Gong, X.J.; et al. Nicotinamide supplementation induces detrimental metabolic and epigenetic changes in developing rats. Br. J. Nutr. 2013, 110, 2156-2164. [CrossRef]

95. Griffin, S.M.; Pickard, M.R.; Orme, R.P.; Hawkins, C.P.; Fricker, R.A. Nicotinamide promotes neuronal differentiation of mouse embryonic stem cells in vitro. Neuroreport 2013, 24, 1041-1046. [CrossRef] [PubMed]

96. Pubchem. 13 Toxicity. National Library of Medicine. Available online: https://pubchem.ncbi.nlm.nih.gov/ compound/Nicotinamide (accessed on 23 April 2020).

97. Lewis, C.M.; Canafax, D.M.; Sprafka, J.M.; Barbosa, J.J. Double-blind randomized trial of nicotinamide on early-onset diabetes. Diabetes Care 1992, 15, 121-123. [CrossRef] [PubMed]

98. Schultz, N.; Lopez, E.; Saleh-Gohari, N.; Helleday, T. Poly(adp-ribose) polymerase (parp-1) has a controlling role in homologous recombination. Nucleic Acids Res. 2003, 31, 4959-4964. [CrossRef] [PubMed]

99. Cefle, K.; Ucur, A.; Guney, N.; Ozturk, S.; Palanduz, S.; Tas, F.; Asoglu, O.; Bayrak, A.; Muslumanoglu, M.; Aydiner, A. Increased sister chromatid exchange frequency in young women with breast cancer and in their first-degree relatives. Cancer Genet. Cytogenet. 2006, 171, 65-67. [CrossRef]

100. Utakoji, T.; Hosoda, K.; Umezawa, K.; Sawamura, M.; Matsushima, T.; Miwa, M.; Sugimura, T. Induction of sister chromatid exchanges by nicotinamide in chinese hamster lung fibroblasts and human lymphoblastoid cells. Biochem. Biophys. Res. Commun. 1979, 90, 1147-1152. [CrossRef]

101. Oikawa, A.; Tohda, H.; Kanai, M.; Miwa, M.; Sugimura, T. Inhibitors of poly(adenosine diphosphate ribose) polymerase induce sister chromatid exchanges. Biochem. Biophys. Res. Commun. 1980, 97, 1311-1316. [CrossRef]

102. Ishidate, M., Jr.; Harnois, M.C.; Sofuni, T. A comparative analysis of data on the clastogenicity of 951 chemical substances tested in mammalian cell cultures. Mutat. Res. 1988, 195, 151-213. [CrossRef]

103. Lindahl-Kiessling, K.; Shall, S. Nicotinamide deficiency and benzamide-induced sister chromatid exchanges. Carcinogenesis 1987, 8, 1185-1188. [CrossRef]

104. Ishidate, M., Jr.; Sofuni, T.; Yoshikawa, K.; Hayashi, M.; Nohmi, T.; Sawada, M.; Matsuoka, A. Primary mutagenicity screening of food additives currently used in japan. Food Chem. Toxicol. 1984, 22, 623-636. [CrossRef]

105. Riklis, E.; Kol, R.; Marko, R. Trends and developments in radioprotection: The effect of nicotinamide on DNA repair. Int. J. Radiat. Biol. 1990, 57, 699-708. [CrossRef]

106. Zhang, T.; Zhou, Y.; Li, L.; Wang, H.H.; Ma, X.S.; Qian, W.P.; Shen, W.; Schatten, H.; Sun, Q.Y. Sirt1, 2, 3 protect mouse oocytes from postovulatory aging. Aging (Albany NY) 2016, 8, 685-696. [CrossRef] [PubMed]

107. Rakieten, N.; Gordon, B.S.; Beaty, A.; Cooney, D.A.; Davis, R.D.; Schein, P.S. Pancreatic islet cell tumors produced by the combined action of streptozotocin and nicotinamide. Proc. Soc. Exp. Biol. Med. 1971, 137, 280-283. [CrossRef] [PubMed]

108. Schoental, R. The role of nicotinamide and of certain other modifying factors in diethylnitrosamine carcinogenesis: Fusaria mycotoxins and "spontaneous" tumors in animals and man. Cancer 1977, 40, 1833-1840. [CrossRef]

109. Handler, P.; Dann, W.J. The inhibition of rat growth by nicotinamide. J. Biol. Chem. 1942, 146, 357-368.

110. Handler, P. The effect of excessive nicotinamide feeding on rabbits and guinea pigs. J. Biol. Chem. 1944, 154, 203-206.

111. Kang-Lee, Y.A.; McKee, R.W.; Wright, S.M.; Swendseid, M.E.; Jenden, D.J.; Jope, R.S. Metabolic effects of nicotinamide administration in rats. J. Nutr. 1983, 113, 215-221. [CrossRef]

112. Mahmoud, Y.I.; Mahmoud, A.A. Role of nicotinamide (vitamin b3) in acetaminophen-induced changes in rat liver: Nicotinamide effect in acetaminophen-damged liver. Exp. Toxicol. Pathol. 2016, 68, 345-354. [CrossRef]

113. Komatsu, M.; Kanda, T.; Urai, H.; Kurokochi, A.; Kitahama, R.; Shigaki, S.; Ono, T.; Yukioka, H.; Hasegawa, K.; Tokuyama, H.; et al. Nnmt activation can contribute to the development of fatty liver disease by modulating the nad (+) metabolism. Sci. Rep. 2018, 8, 8637. [CrossRef]

114. Harrison, I.F.; Powell, N.M.; Dexter, D.T. The histone deacetylase inhibitor nicotinamide exacerbates neurodegeneration in the lactacystin rat model of parkinson's disease. J. Neurochem. 2019, 148, 136-156. [CrossRef] 
115. Rakieten, N.; Gordon, B.S.; Beaty, A.; Cooney, D.A.; Schein, P.S.; Dixon, R.L. Modification of renal tumorigenic effect of streptozotocin by nicotinamide: Spontaneous reversibility of streptozotocin diabetes. Proc. Soc. Exp. Biol. Med. 1976, 151, 356-361. [CrossRef]

116. Jiang, S.; Wang, W.; Miner, J.; Fromm, M. Cross regulation of sirtuin 1, ampk, and ppargamma in conjugated linoleic acid treated adipocytes. PLoS ONE 2012, 7, e48874. [CrossRef]

117. Trammell, S.A.; Schmidt, M.S.; Weidemann, B.J.; Redpath, P.; Jaksch, F.; Dellinger, R.W.; Li, Z.; Abel, E.D.; Migaud, M.E.; Brenner, C. Nicotinamide riboside is uniquely and orally bioavailable in mice and humans. Nat. Commun. 2016, 7, 12948. [CrossRef]

118. Revollo, J.R.; Korner, A.; Mills, K.F.; Satoh, A.; Wang, T.; Garten, A.; Dasgupta, B.; Sasaki, Y.; Wolberger, C.; Townsend, R.R.; et al. Nampt/pbef/visfatin regulates insulin secretion in beta cells as a systemic nad biosynthetic enzyme. Cell Metab. 2007, 6, 363-375. [CrossRef]

119. Muthukrishnan, S.; Both, G.W.; Furuichi, Y.; Shatkin, A.J. 5'-terminal 7-methylguanosine in eukaryotic mrna is required for translation. Nature 1975, 255, 33-37. [CrossRef] [PubMed]

120. Sonenberg, N.; Rupprecht, K.M.; Hecht, S.M.; Shatkin, A.J. Eukaryotic mrna cap binding protein: Purification by affinity chromatography on sepharose-coupled m7gdp. Proc. Natl. Acad. Sci. USA 1979, 76, 4345-4349. [CrossRef] [PubMed]

121. Knip, M.; Douek, I.F.; Moore, W.P.; Gillmor, H.A.; McLean, A.E.; Bingley, P.J.; Gale, E.A.; European Nicotinamide Diabetes Intervention Trial Group. Safety of high-dose nicotinamide: A review. Diabetologia 2000, 43, 1337-1345. [CrossRef] [PubMed]

122. Felsted, R.L.; Chaykin, S. N1-methylnicotinamide oxidation in a number of mammals. J. Biol. Chem. 1967, 242, 1274-1279. [PubMed]

123. Mrochek, J.E.; Jolley, R.L.; Young, D.S.; Turner, W.J. Metabolic response of humans to ingestion of nicotinic acid and nicotinamide. Clin. Chem. 1976, 22, 1821-1827. [CrossRef]

124. Attwood, J.T.; Yung, R.L.; Richardson, B.C. DNA methylation and the regulation of gene transcription. Cell. Mol. Life Sci. 2002, 59, 241-257. [CrossRef]

125. Robertson, K.D. DNA methylation and human disease. Nat. Rev. Genet. 2005, 6, 597-610. [CrossRef]

126. Drong, A.W.; Lindgren, C.M.; McCarthy, M.I. The genetic and epigenetic basis of type 2 diabetes and obesity. Clin. Pharmacol. Ther. 2012, 92, 707-715. [CrossRef] [PubMed]

127. Lee, D.Y.; Teyssier, C.; Strahl, B.D.; Stallcup, M.R. Role of protein methylation in regulation of transcription. Endocr. Rev. 2005, 26, 147-170. [CrossRef]

128. Finkelstein, J.D.; Martin, J.J. Homocysteine. Int. J. Biochem. Cell Biol. 2000, 32, 385-389. [CrossRef]

129. Cosmetic Ingredient Review Expert Panel. Final report of the safety assessment of niacinamide and niacin. Int. J. Toxicol. 2005, 24 (Suppl. 5), 1-31.

130. Pissios, P. Nicotinamide n-methyltransferase: More than a vitamin b3 clearance enzyme. Trends Endocrinol. Metab. 2017, 28, 340-353. [CrossRef] [PubMed]

131. Tian, Y.J.; Li, D.; Ma, Q.; Gu, X.Y.; Guo, M.; Lun, Y.Z.; Sun, W.P.; Wang, X.Y.; Cao, Y.; Zhou, S.S. Excess nicotinamide increases plasma serotonin and histamine levels. Sheng Li Xue Bao 2013, 65, 33-38. [PubMed]

132. Burgos, E.S.; Schramm, V.L. Weak coupling of atp hydrolysis to the chemical equilibrium of human nicotinamide phosphoribosyltransferase. Biochemistry 2008, 47, 11086-11096. [CrossRef]

133. Hara, N.; Yamada, K.; Shibata, T.; Osago, H.; Tsuchiya, M. Nicotinamide phosphoribosyltransferase/visfatin does not catalyze nicotinamide mononucleotide formation in blood plasma. PLoS ONE 2011, 6, e22781. [CrossRef]

134. Zhou, S.S.; Li, D.; Sun, W.P.; Guo, M.; Lun, Y.Z.; Zhou, Y.M.; Xiao, F.C.; Jing, L.X.; Sun, S.X.; Zhang, L.B.; et al. Nicotinamide overload may play a role in the development of type 2 diabetes. World J. Gastroenterol. 2009, 15, 5674-5684. [CrossRef]

135. Kannt, A.; Rajagopal, S.; Kadnur, S.V.; Suresh, J.; Bhamidipati, R.K.; Swaminathan, S.; Hallur, M.S.; Kristam, R.; Elvert, R.; Czech, J.; et al. A small molecule inhibitor of nicotinamide n-methyltransferase for the treatment of metabolic disorders. Sci. Rep. 2018, 8, 3660. [CrossRef]

136. Schmeisser, K.; Mansfeld, J.; Kuhlow, D.; Weimer, S.; Priebe, S.; Heiland, I.; Birringer, M.; Groth, M.; Segref, A.; Kanfi, Y.; et al. Role of sirtuins in lifespan regulation is linked to methylation of nicotinamide. Nat. Chem. Biol. 2013, 9, 693-700. [CrossRef] [PubMed]

137. Riederer, M.; Erwa, W.; Zimmermann, R.; Frank, S.; Zechner, R. Adipose tissue as a source of nicotinamide n-methyltransferase and homocysteine. Atherosclerosis 2009, 204, 412-417. [CrossRef] [PubMed] 
138. Hemati, T.; Moghadami-Tabrizi, N.; Davari-Tanha, F.; Salmanian, B.; Javadian, P. High plasma homocysteine and insulin resistance in patients with polycystic ovarian syndrome. Iran. J. Reprod. Med. 2011, 9, 223-228.

139. Yang, N.; Yao, Z.; Miao, L.; Liu, J.; Gao, X.; Fan, H.; Hu, Y.; Zhang, H.; Xu, Y.; Qu, A.; et al. Novel clinical evidence of an association between homocysteine and insulin resistance in patients with hypothyroidism or subclinical hypothyroidism. PLoS ONE 2015, 10, e0125922. [CrossRef]

140. Akintunde, A.; Nondi, J.; Gogo, K.; Jones, E.S.W.; Rayner, B.L.; Hackam, D.G.; Spence, J.D. Physiological phenotyping for personalized therapy of uncontrolled hypertension in africa. Am. J. Hypertens. 2017, 30, 923-930. [CrossRef]

141. Feng, X.; Xu, Y. Hyperhomocysteinemia as a metabolic risk factor for glucose intolerance among high-risk groups of Chinese adults. Med. Sci. Monit. 2017, 23, 2775-2781. [CrossRef]

142. Cardellini, M.; Perego, L.; D’Adamo, M.; Marini, M.A.; Procopio, C.; Hribal, M.L.; Andreozzi, F.; Frontoni, S.; Giacomelli, M.; Paganelli, M.; et al. C-174g polymorphism in the promoter of the interleukin- 6 gene is associated with insulin resistance. Diabetes Care 2005, 28, 2007-2012. [CrossRef]

143. Senn, J.J.; Klover, P.J.; Nowak, I.A.; Mooney, R.A. Interleukin-6 induces cellular insulin resistance in hepatocytes. Diabetes 2002, 51, 3391-3399. [CrossRef]

144. Li, Y.; Zhang, H.; Jiang, C.; Xu, M.; Pang, Y.; Feng, J.; Xiang, X.; Kong, W.; Xu, G.; Li, Y.; et al. Hyperhomocysteinemia promotes insulin resistance by inducing endoplasmic reticulum stress in adipose tissue. J. Biol. Chem. 2013, 288, 9583-9592. [CrossRef]

145. Villalobos-Labra, R.; Subiabre, M.; Toledo, F.; Pardo, F.; Sobrevia, L. Endoplasmic reticulum stress and development of insulin resistance in adipose, skeletal, liver, and foetoplacental tissue in diabesity. Mol. Asp. Med. 2019, 66, 49-61. [CrossRef]

146. Xu, J.; Xu, S.Q.; Liang, J.; Lu, Y.; Luo, J.H.; Jin, J.H. Protective effect of nicotinamide in a mouse parkinson's disease model. Zhejiang Da Xue Xue Bao Yi Xue Ban 2012, 41, 146-152. [PubMed]

147. Williams, A.C.; Ramsden, D.B. Autotoxicity, methylation and a road to the prevention of parkinson's disease. J. Clin. Neurosci. 2005, 12, 6-11. [CrossRef] [PubMed]

148. Matsubara, K.; Aoyama, K.; Suno, M.; Awaya, T. N-methylation underlying parkinson's disease. Neurotoxicol. Teratol. 2002, 24, 593-598. [CrossRef]

149. Parsons, R.B.; Smith, S.W.; Waring, R.H.; Williams, A.C.; Ramsden, D.B. High expression of nicotinamide n-methyltransferase in patients with idiopathic parkinson's disease. Neurosci. Lett. 2003, 342, 13-16. [CrossRef]

150. Fukushima, T. Niacin metabolism and parkinson's disease. Environ. Health Prev. Med. 2005, 10, 3-8. [CrossRef] [PubMed]

151. Fukushima, T.; Kaetsu, A.; Lim, H.; Moriyama, M. Possible role of 1-methylnicotinamide in the pathogenesis of parkinson's disease. Exp. Toxicol. Pathol. 2002, 53, 469-473. [CrossRef]

152. Liu, M.; Chu, J.; Gu, Y.; Shi, H.; Zhang, R.; Wang, L.; Chen, J.; Shen, L.; Yu, P.; Chen, X.; et al. Serum n1-methylnicotinamide is associated with coronary artery disease in chinese patients. J. Am. Heart Assoc. 2017, 6, e004328. [CrossRef]

153. Siasos, G.; Tsigkou, V.; Kosmopoulos, M.; Theodosiadis, D.; Simantiris, S.; Tagkou, N.M.; Tsimpiktsioglou, A.; Stampouloglou, P.K.; Oikonomou, E.; Mourouzis, K.; et al. Mitochondria and cardiovascular diseases-from pathophysiology to treatment. Ann. Transl. Med. 2018, 6, 256. [CrossRef]

154. Shai, I.; Stampfer, M.J.; Ma, J.; Manson, J.E.; Hankinson, S.E.; Cannuscio, C.; Selhub, J.; Curhan, G.; Rimm, E.B. Homocysteine as a risk factor for coronary heart diseases and its association with inflammatory biomarkers, lipids and dietary factors. Atherosclerosis 2004, 177, 375-381. [CrossRef]

155. Zhang, R.; Shen, Y.; Zhou, L.; Sangwung, P.; Fujioka, H.; Zhang, L.; Liao, X. Short-term administration of nicotinamide mononucleotide preserves cardiac mitochondrial homeostasis and prevents heart failure. $J$. Mol. Cell. Cardiol. 2017, 112, 64-73. [CrossRef]

156. Diguet, N.; Trammell, S.A.J.; Tannous, C.; Deloux, R.; Piquereau, J.; Mougenot, N.; Gouge, A.; Gressette, M.; Manoury, B.; Blanc, J.; et al. Nicotinamide riboside preserves cardiac function in a mouse model of dilated cardiomyopathy. Circulation 2018, 137, 2256-2273. [CrossRef] [PubMed]

157. Aksoy, S.; Szumlanski, C.L.; Weinshilboum, R.M. Human liver nicotinamide n-methyltransferase. Cdna cloning, expression, and biochemical characterization. J. Biol. Chem. 1994, 269, 14835-14840. [PubMed] 
158. Parsons, W.B., Jr. Studies of nicotinic acid use in hypercholesteremia. Changes in hepatic function, carbohydrate tolerance, and uric acid metabolism. Arch. Intern. Med. 1961, 107, 653-667. [CrossRef] [PubMed]

159. Volpi, E.; Lucidi, P.; Cruciani, G.; Monacchia, F.; Reboldi, G.; Brunetti, P.; Bolli, G.B.; De Feo, P. Nicotinamide counteracts alcohol-induced impairment of hepatic protein metabolism in humans. J. Nutr. 1997, 127, 2199-2204. [CrossRef]

160. Strom, K.; Morales-Alamo, D.; Ottosson, F.; Edlund, A.; Hjort, L.; Jorgensen, S.W.; Almgren, P.; Zhou, Y.; Martin-Rincon, M.; Ekman, C.; et al. N(1)-methylnicotinamide is a signalling molecule produced in skeletal muscle coordinating energy metabolism. Sci. Rep. 2018, 8, 3016. [CrossRef]

161. Kannt, A.; Pfenninger, A.; Teichert, L.; Tonjes, A.; Dietrich, A.; Schon, M.R.; Kloting, N.; Bluher, M. Association of nicotinamide-n-methyltransferase mrna expression in human adipose tissue and the plasma concentration of its product, 1-methylnicotinamide, with insulin resistance. Diabetologia 2015, 58, 799-808. [CrossRef]

162. Hong, S.; Moreno-Navarrete, J.M.; Wei, X.; Kikukawa, Y.; Tzameli, I.; Prasad, D.; Lee, Y.; Asara, J.M.; Fernandez-Real, J.M.; Maratos-Flier, E.; et al. Nicotinamide n-methyltransferase regulates hepatic nutrient metabolism through sirt1 protein stabilization. Nat. Med. 2015, 21, 887-894. [CrossRef]

163. Takeuchi, K.; Yokouchi, C.; Goto, H.; Umehara, K.; Yamada, H.; Ishii, Y. Alleviation of fatty liver in a rat model by enhancing $\mathrm{n}(1)$-methylnicotinamide bioavailability through aldehyde oxidase inhibition. Biochem. Biophys. Res. Commun. 2018, 507, 203-210. [CrossRef]

164. Chlopicki, S.; Swies, J.; Mogielnicki, A.; Buczko, W.; Bartus, M.; Lomnicka, M.; Adamus, J.; Gebicki, J. 1-methylnicotinamide (mna), a primary metabolite of nicotinamide, exerts anti-thrombotic activity mediated by a cyclooxygenase-2/prostacyclin pathway. Br. J. Pharmacol. 2007, 152, 230-239. [CrossRef]

165. Menon, R.M.; Adams, M.H.; Gonzalez, M.A.; Tolbert, D.S.; Leu, J.H.; Cefali, E.A. Plasma and urine pharmacokinetics of niacin and its metabolites from an extended-release niacin formulation. Int. J. Clin. Pharmacol. Ther. 2007, 45, 448-454. [CrossRef]

166. Vanholder, R.; De Smet, R.; Glorieux, G.; Argiles, A.; Baurmeister, U.; Brunet, P.; Clark, W.; Cohen, G.; De Deyn, P.P.; Deppisch, R.; et al. Review on uremic toxins: Classification, concentration, and interindividual variability. Kidney Int. 2003, 63, 1934-1943. [CrossRef] [PubMed]

167. Rutkowski, B.; Slominska, E.; Szolkiewicz, M.; Smolenski, R.T.; Striley, C.; Rutkowski, P.; Swierczynski, J. N-methyl-2-pyridone-5-carboxamide: A novel uremic toxin? Kidney Int. 2003, 63, S19-S21. [CrossRef] [PubMed]

168. Chen, A.C.; Martin, A.J.; Choy, B.; Fernandez-Penas, P.; Dalziell, R.A.; McKenzie, C.A.; Scolyer, R.A.; Dhillon, H.M.; Vardy, J.L.; Kricker, A.; et al. A phase 3 randomized trial of nicotinamide for skin-cancer chemoprevention. N. Engl. J. Med. 2015, 373, 1618-1626. [CrossRef] [PubMed]

169. O'Brien, T.; Silverberg, J.D.; Nguyen, T.T. Nicotinic acid-induced toxicity associated with cytopenia and decreased levels of thyroxine-binding globulin. Mayo Clin. Proc. 1992, 67, 465-468. [CrossRef]

170. Tian, Y.J.; Luo, N.; Chen, N.N.; Lun, Y.Z.; Gu, X.Y.; Li, Z.; Ma, Q.; Zhou, S.S. Maternal nicotinamide supplementation causes global DNA hypomethylation, uracil hypo-incorporation and gene expression changes in fetal rats. Br. J. Nutr. 2014, 111, 1594-1601. [CrossRef] [PubMed]

171. Zhao, Y.; Liu, M.; Chan, X.Y.; Tan, S.Y.; Subramaniam, S.; Fan, Y.; Loh, E.; Chang, K.T.E.; Tan, T.C.; Chen, Q. Uncovering the mystery of opposite circadian rhythms between mouse and human leukocytes in humanized mice. Blood 2017, 130, 1995-2005. [CrossRef] [PubMed]

172. Yan, L.; Otterness, D.M.; Weinshilboum, R.M. Human nicotinamide n-methyltransferase pharmacogenetics: Gene sequence analysis and promoter characterization. Pharmacogenetics 1999, 9, 307-316. [CrossRef]

(C) 2020 by the authors. Licensee MDPI, Basel, Switzerland. This article is an open access article distributed under the terms and conditions of the Creative Commons Attribution (CC BY) license (http://creativecommons.org/licenses/by/4.0/). 